\title{
BIRTH AND LIFE OF SCIENTIFIC COLLECTIONS IN FLORENCE
}

Mara Miniati '

\section{RESUMO:}

O artigo centra-se na história das coleções científicas em Florença. $\mathrm{Na}$ era dos Medici, Florença foi um importante centro de pesquisa científica e de coleções. Este aspecto da cultura florentina é geralmente menos conhecido, mas a ciência e coleções científicas foram uma parte consistente da história da cidade. $O$ recolhimento de instrumentos científicos era um componente importante das estratégias políticas dos grão-duques florentinos, convencidos de que o conhecimento científico e controle tecnológico sobre a natureza conferiria solidez e prestígio ao seu poder político. De Cosimo I a Cosimo III, os grão-duques Médici concederam o seu patrocínio e comissões sobre gerações de engenheiros e cientistas, formando uma coleção de instrumentos matemáticos e astronômicos, os modelos científicos e produtos naturais, exibidos ao lado das mais famosas coleções de arte na Galleria Uffizi, no Palazzo Pitti, e em torno da cidade de Florença e outros lugares da Toscana. Esta coleção soberba, ainda existente, é uma expressão não só do "gosto" dos tempos, mas também dos interesses multifacetados do grão-duques. Após o fim da era Medici, no século I8, a dinastia Lorena Florence separou as coleções artísticas das coleções científicas e estas últimas foram colocados no novo Museu Imperial e Real de Física e História Natural, pelo Grão-Duque Pedro Leopoldo de Lorena e aberta ao público em I775. A fundação deste museu pela dinastia Lorena representou um novo desenvolvimento e uma nova fase para esse material de interesse científico em Florença. Este artigo descreve as transformações ocorridas entre os séculos 18 e I9 na vida cultural da capital da Toscana: as artes e ciências foram promovidos, e os florentinos cultivados estavam interessadas no desenvolvimento recente da física, na Itália e no exterior. Nesse período, numerosas coleções científicas privadas e públicas de Florença existentes, que eram menos famosas, mas não menos importantes do que as coleções Médici e Lorena se destacaram. Finalmente, o artigo descreve como as coleções florentinas se desenvolveram. A fundação do Instituto e Museu de História da Ciência deu nova atenção aos instrumentos científicos antigos. Sua intensa atividade de pesquisa teve um impacto sobre a organização do Museu. Novos estudos levaram a novas atribuições aos instrumentos científicos, as investigações de arquivamento contribuiram para um melhor conhecimento da coleção, e os contactos crescentes com instituições italianas e internacionais feitas do Museu tornaram-no cada vez mais ativo em uma ampla rede de empreendimentos cooperativos sobre temas específicos. A última alteração de sua denominação (Museo Galileo) e a reorganização moderna são a expressão de uma "continuidade" do patrimônio histórico-científico, preservado pelo Museu, e do "Inovação" para permiti-lo "falar" e torna-lo inteligível a um público contemporâneo.

\section{PALAVRAS-CHAVE}

Coleções Científicas; história; Florença; Médici; Museu Galileu.

IEmeritus Curator Museo Galileo, Florence; President Scientific Committee Fondazione Scienza e Tecnica, Florence 


\section{BIRTH AND LIFE OF SCIENTIFIC COLLECTIONS IN FLORENCE}

\begin{abstract}
The paper focuses on the history of the scientific collections in Florence. In the age of Medici, Florence was an important centre of scientific research and collections. This aspect of Florentine culture is generally less known, but science and scientific collections were a consistent part of the story of the city. At the same time, collecting scientific instruments was an important component of the political strategies of the Florentine Grand Dukes, convinced thats cientific knowledg and technological control over nature would confersolidity and prestige on political power. From Cosimo I to Cosimolll, the Medici Grand Dukes best owed their patronage and commissions on generations of engineers and scientists, for minga collection of mathematical and astronomical instruments, scientific models and natural products, displayed along side the more famous collections of art in the Galleria degli Uffizi, in Palazzo Pitti, and around the city of Florence and other places in Tuscany. This superb collection, still existing, is an expression not only of the 'taste' of the times but also of the multifaceted interests of the Grand Dukes.After the end of the Medici age, the I8th century Lorraine Florence separated the artistic collections from the scientific collections: the latter were placed in the new Imperial and Royal Museum of Physics and Natural History, wanted by the Grand Duke Peter Leopold of Lorraine and opened in 1775. The founding of this museum by the Lorraine dynasty represented the new development and the consideration of the material of scien-
\end{abstract}

tific interest in Florence. This paper describes the transformations between the 18th and 19th century and the cultural life in the Tuscan capital: the arts and sciences were promoted, and Florentine cultivated people were interested in the recent development in physics, in Italy and abroad. In that period numerous, private and public scientific collections in Florence existed, which were less famous, but not less important than the Medicean and Lorraine collections. Finally, the paper describes how the Florentine collections continue their life. The founding of the Istituto e Museo di Storia della Scienza gave new attention to the ancient instruments of science. Its intense research activity had an impact on the organization of the Museum. New studies led to new attributions for scientific instruments, archival investigations contributed to a better knowledge of the collection, and the growing contacts with Italian and international institutions made the Museum an increasingly active node in a wide network of cooperative ventures on specific topics. The last change of its name (Museo Galileo) and a new, modern reorganization are the expression of a 'continuity' of the historical scientific heritage preserved by the Museum, and of the 'Innovation' to make it "speak" and render it intelligible to a contemporary public.

\section{KEYWORDS}

Scientific Collections; history; Florence; Medici; Galileo Museum. 
The relationship between Florence and science is very ancient. Particularly in the 14th and 15th centuries, the city was the theatre of a true Renaissance of science. Archimedes was the legendary figure of reference for generations of mechanical engineers: Filippo Brunelleschi (I377-I446), Mariano di Jacopo, known as Taccola (I382 - I453 c.), Francesco di Giorgio Martini (I439-I50I) and Leonardo da Vinci (I452-I5I9) remain inextricably linked to the invention of astonishing machines - for warfare, hydraulics, construction sites and entertainment - that anticipated the progress in mechanical science achieved in the following century by Guidobaldo del Monte (I545-1607) and Galileo Galilei (I564-1642).

The myth of Archimedes favoured the affirmation of two new professional figures: the artist-engineer, not a simple 'mechanic', but an authority in ancient technology, author, and partner in a dialogue between literates and humanists; and the engineer-scientist, who operated in the major European universities in the sixteenth century, and contributed to make the ars mechanica a mathematical discipline. Florentines as Paolo dal Pozzo Toscanelli (I397-I482) and Amerigo Vespucci (I454-I5I2) contributed to.

With the discovery of the New World, geographic works were compiled to update the information based on Ptolemaic science. Humanists' libraries abounded in geographic books and many sumptuous, costly codices were produced by Florentine workshops in the I5th century. Lorenzo the Magnificent (I449-I492) owned numerous geographical maps and a superb codex of the Geografia 'painted' by Piero del Massaio (I5th century), which then passed into the hands of Cosimo I (I5I9-I574).

In the age of Medici, Florence was an important centre of scientific research and collections. This aspect of the Florentine culture is generally less known, but science and scientific collections were a consistent part of the story of the city. At the same time, collecting scientific instruments was an important component of the political strategies of the Florentine Grand Dukes, convinced that scientific knowledge and technological control over nature would confer solidity and prestige on political power.

From Cosimo I (1519-I574) to Cosimo III (1642-1723), the Medici Grand Dukes bestowed their patronage and commissions on generations of engineers and scientists, forming a collection of mathematical and astronomical instruments, scientific models and natural products, displayed alongside the more famous collections of art in the Galleria degli Uffizi, in Palazzo Pitti, and around the city of Florence and other places in Tuscany. This superb collection, still existing, is an expression not only of the 'taste' of the times but also of the multifaceted interests that the Grand Dukes focused their attention on. The Florentine scientific museums preserve it: for instance, scientific instruments are now preserved in the Museo Galileo, stuffed animals in 'La Specola', herbaria in Museum of Botany and so on (CAMEROTA, MINIATI, 2008)2.

\section{Medicean scientific collections (I537-I734)}

The young Cosimo de Medici ascended to the throne in 1537, and managed to free himself from Imperial dominance, creating a modern territorial and patrimonial state controlled by the Medici dynasty. Cosimo I surrounded himself with 'new men', possessing the technical, artistic, scientific, administrative, strategic and organizational capabilities suited to the new requisites. He commissioned the scientist Luca Ghini, from Imola, to create the Botanical

2 This paper focuses, above all, the rich collection of measuring instruments, mathematical and astronomical, today preserved in the Museo Galileo in Florence. 
Garden in Pisa (I544), and Niccolò, called "II Tribolo", to design the Botanical Garden in Florence, the so-called 'Orto dei Semplici' (I545).

At the same time, Cosimo began to be concerned with the image of his power as well, launching a complex programme to renovate the ancient Palazzo dei Priori, known as Palazzo Vecchio. Conceived by Cosimo himself, the project included the arrangement of the Maps Room, where Cosimo I, playing on the words "Cosimo/Kosmos", celebrated his own person through a grandiose decorative scheme that reproduced on the walls of the room the pages of the Cosmography by Ptolemy. Giorgio Vasari (I5II-I574) was entrusted with the task of redesigning and enlarging the building. The 53 geographical charts "after Ptolemy" (originally 57), with represented both the ancient world and the recently discovered lands, were commissioned of the cosmographer Egnazio Danti (I536- I586) and carried out by his successor Stefano Buonsignori (?-I 589). The Maps Room of Palazzo Vecchio was destined to house the most important, precious and beautiful things owned by the Grand Duke. The project, which remained unfinished, also provided for representations of animals and plants native to the countries depicted in the charts, a series of busts of emperors and princes of the various nations, three hundred portraits of illustrious men and, on the ceiling, a representation of the constellations. Two huge globes (a terrestrial and a celestial one) would descend from the ceiling at command, through a strikingly effective scenic artifice, a terrestrial one, displayed today in the hall, and a celestial one, perhaps never built (CAMEROTA, 20I0).

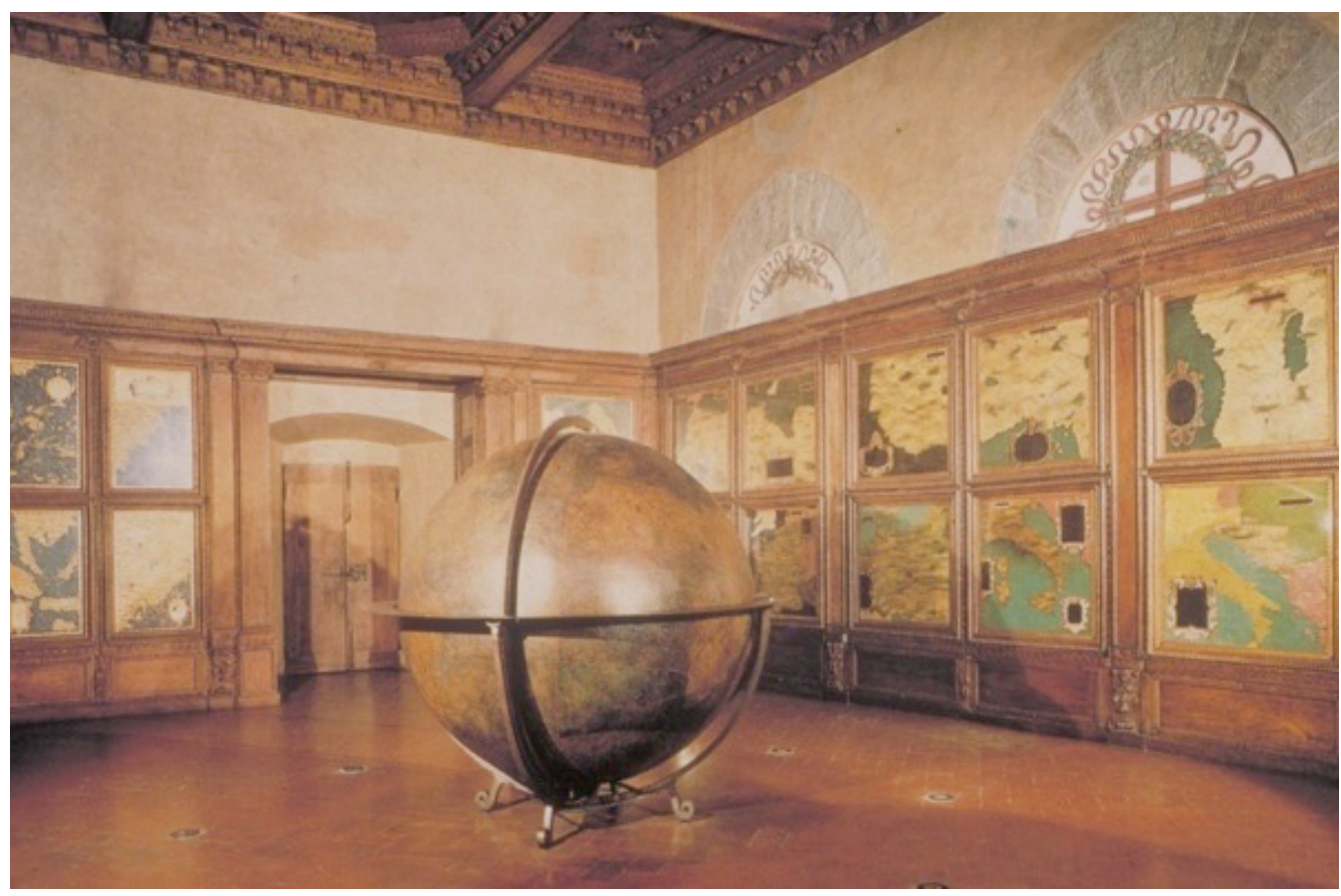

Globo - Egnazio Danti - Palazzo Vecchio - Florence

In 1562 Cosimo created the role of cosmographer and Danti obtained this charge, and built splendid astronomical and mathematical instruments for the Medici collection. In 1569, Cosimo de' Medici persuaded Pope Pius V (I504-1572) to work for a calendar reform that would eliminate the ten-day delay with which the spring equinox, established as March 2I, occurred with respect to the true astronomical equinox. The liturgically exact date of Easter and the related movable feasts depended on the correct date of the equinox. 
Cosimo's commitment consisted of transforming the church of Santa Maria Novella into a sort of astronomical observatory, and the cosmographer Egnazio Danti was commissioned to construct the instruments required for the observations and for measuring the movements of the Sun. Between 1572 and 1575, on the façade of the church, Danti installed three instruments specially constructed for observing the equinoxes and solstices, and still existing today. The project was interrupted by the death of Cosimo and by Danti's departure from Florence in 1575 at the order of the new Grand Duke Francesco I (SETTLE, 2008).

When Cosimo I died in I574 the collection abounded in instruments made by Italian and particularly Florentine craftsmen and foreign authors: the inventories of the Guardaroba Medicea in Palazzo Vecchio record dividers and sundials, astrolabes and surveying instruments, nocturnals and quadrants, made also by German makers.

Francesco I (I54I-I587) built a sort of secular chapel in Palazzo Vecchio, the so-called "Studiolo", which contained works of art, naturalistic objects and some of the most important products of the Medici Foundry. For this room, Vincenzo Borghini (I5I5-I580) designed a complex iconographic program: to trace the location of the objects in the cabinet, it was necessary to follow a mental itinerary of a mnemonic nature. The memory path for the objects started from their natural origin (one of the four elements represented on the ceiling), then went on to their

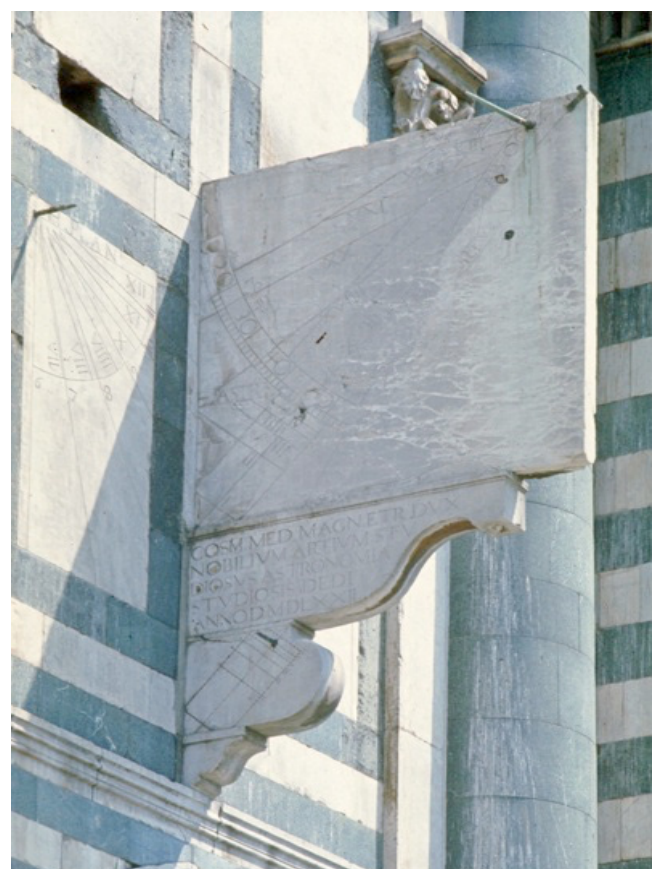

Quadrant SMN

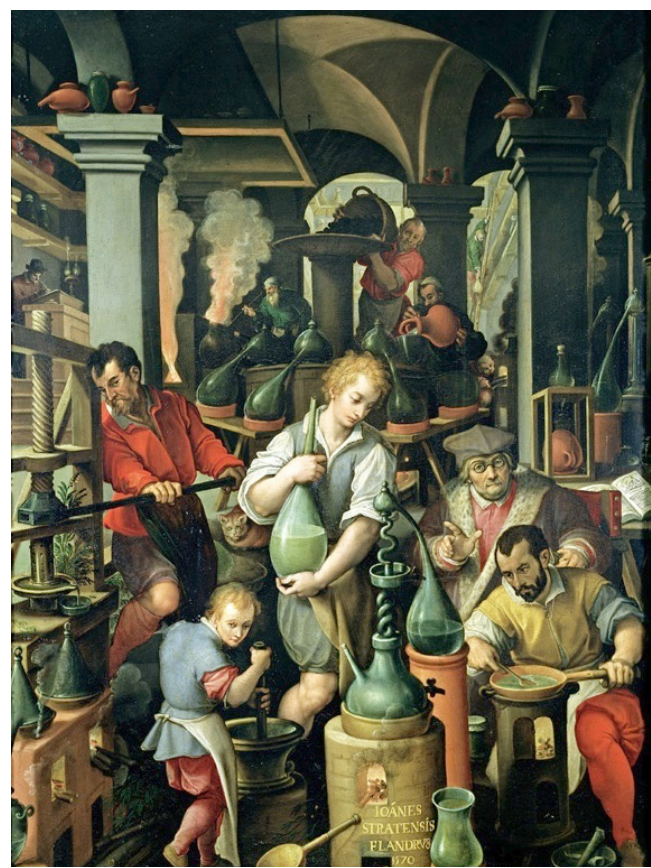

Scena Studiolo mythological or historical significance and lastly, in many cases, to their technical features (cabinet doors and slates).

The Olivetan monk Stefano Buonsignori was called as new cosmographer of the Grand Duke. The engineer, topographer and mathematician Antonio Lupicini also worked for Francesco: he supervised the "Teoricae planetarum", that is four armillary spheres begun in 1570, completed in 1574, and realized by many different workers and artists, including the famous sculptor Valerio Cioli (I529-I599). The spheres were given to the Laurentian Library where they are still today (DEKKER, 2004, pp. 32-5I; CAMEROTA, MINIATI, 2008, Pp. I64-I65). 
At the same time, Francesco I founded the Galleria degli Uffizi where the merits of the Medici family as private collectors were celebrated. In this perspective, the Tribuna built by Bernardo Buontalenti in the early I580s had a peculiar importance.

The new Grand Duke, Ferdinando I (1549-1609) inserted the Tribuna within a broader museum project, which included the Maps Room, the Room of Military Architecture and the four rooms of the Armoury. This ensemble was conceived to promote the relationship between art and science, and provide a symbolic tribute to the family genealogy. He resumed the cosmographic project promoted by his father, Cosimo I, in Palazzo Vecchio, with a new 'Cosmography Room' set up in the Galleria degli Uffizi. In this Room some frescoes represented the domains - the Florentine Domain and the Sienese Domain - which his father had acquired thanks to the annexation of Siena. In the same Room two important objects were also placed: the great terrestrial globe made by Egnazio Danti for the Palazzo Vecchio, and a monumental armillary sphere specially commissioned to the cosmographer Antonio Santucci (?-16/3).

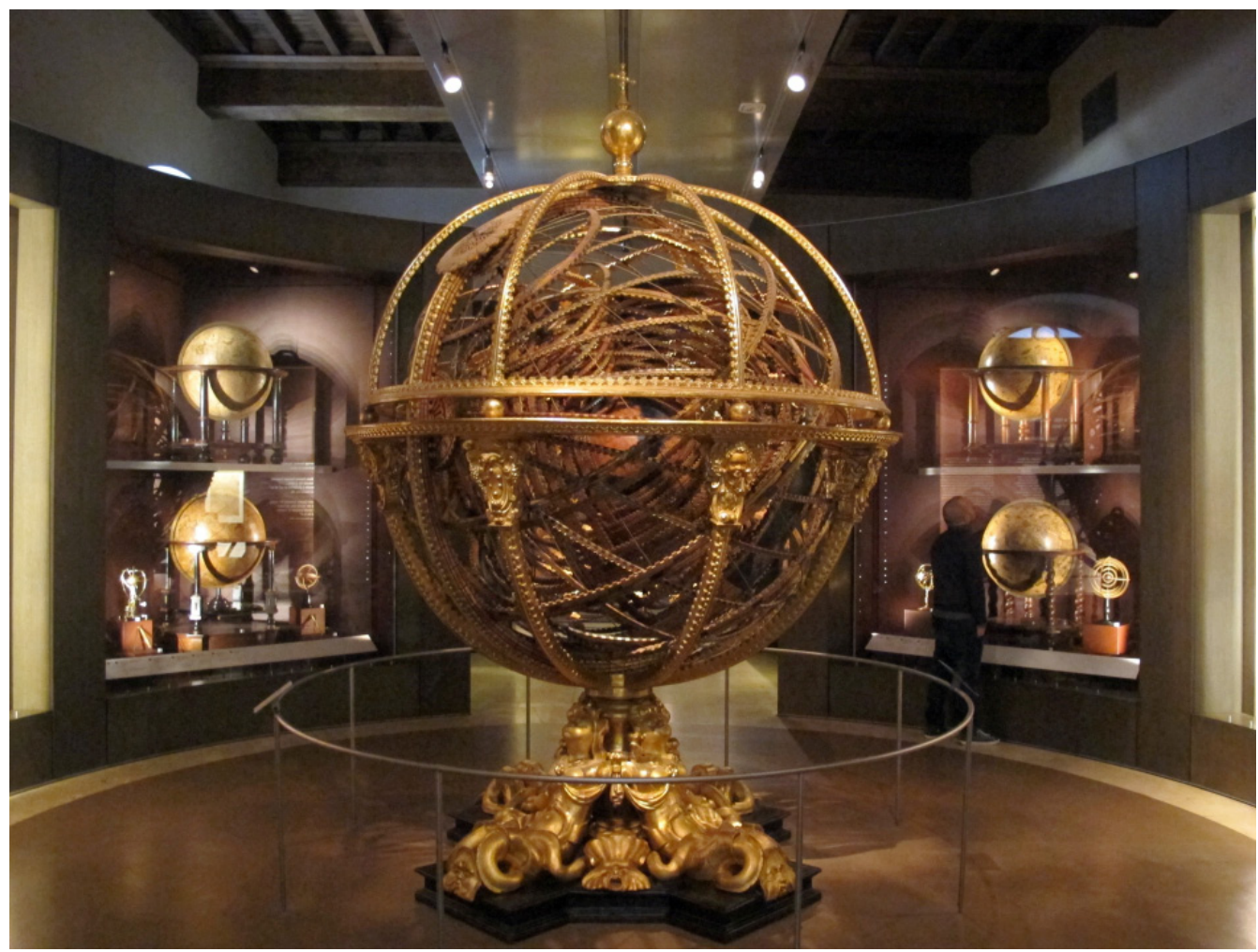

Santucci, sfera armillare

The Cosmography Room of the Uffizi Gallery emblematically exalted the name of Cosimo by evoking the three forms of representation of Ptolemaic cosmography, namely, "cosmography" proper, that is, the image of the sky, represented by Santucci's armillary sphere;"'geography”, represented by Danti's terrestrial globe; and "chorography", represented by the regional maps of grandducal Tuscany, painted by Ludovico Buti (I560-I6II I). on the basis of two maps drawn by Stefano Buonsignori to illustrate the Vita di Cosimo I (Life of Cosimo I), published by Aldo Manuzio the Younger in 1586. 


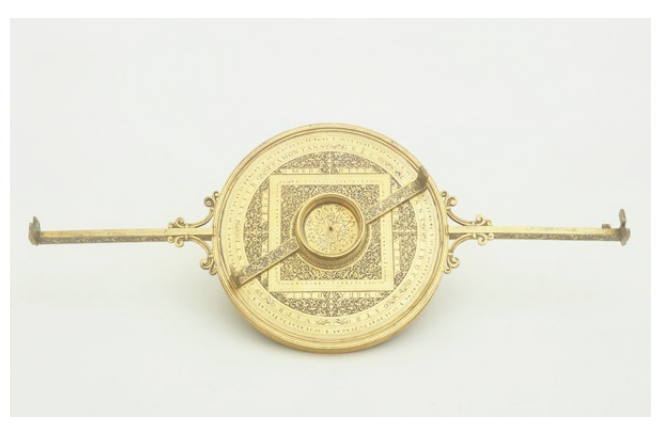

Topographic Compass

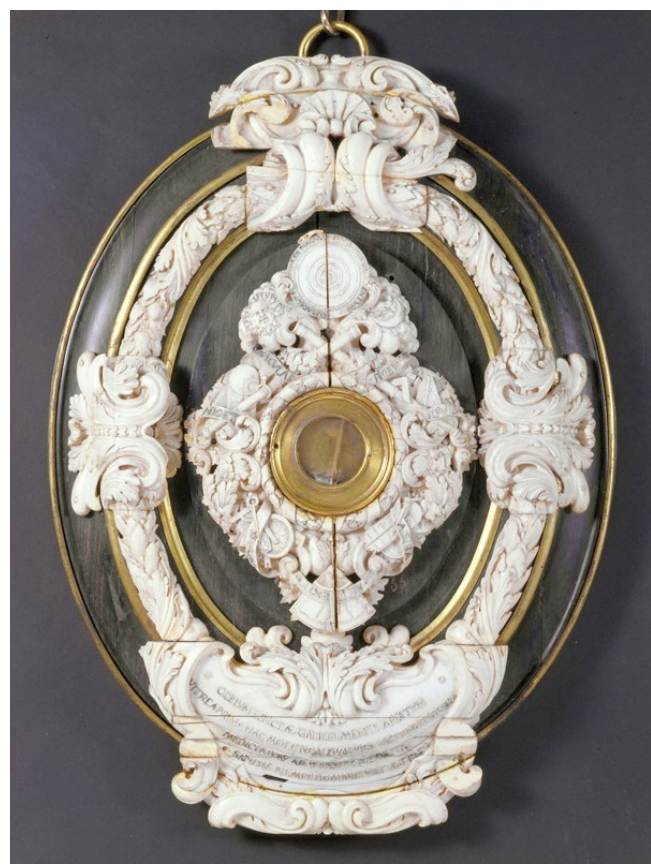

Objective Lens

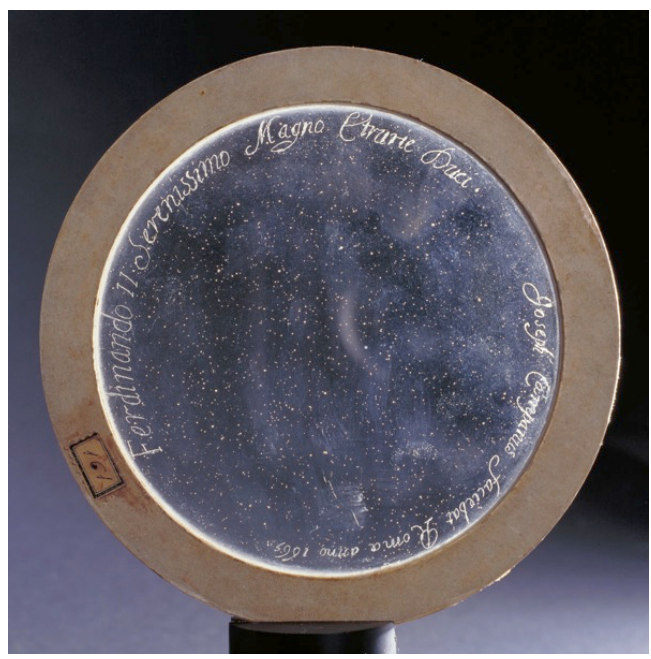

Campani Lens
Another room, the Room of Military Architecture, better known as the Stanzino delle Matematiche, was the image of Medicean political and cultural power. Ferdinando I rearranged here at the end of the century the first group of scientific instruments collected by Cosimo I, together with books, drawings, navigation manuals and geographc maps.

Son of Ferdinando and Cristina di Lorena, the young Cosimo (1590I62I) became Grand Duke in 1609. Before, he had been a student of Galileo Galilei (1564-1642) and, in 1606, had received the treatise on the new instrument invented by the scientist, and the instrument itself, the geometric and military sector. Both, treatise and sector, were put in the "Stanzino", together with other mathematical instruments.

In 1609, the "cosmographic" celebration of the Medici was further improved by Galileo's astronomical discoveries. The satellites of Jupiter he had discovered, called Medicean Stars, could be used as an astronomical clock, and the lens he had employed in his astronomical enquiries was preserved as a relic. Galileo left the Medici a lodestone armed with iron, a presentation exemplar of the telescope and the objective lens with which he had discovered the satellites of Jupiter.

This last piece was received only after the death of Galileo, under the initiative of Vincenzo Viviani, his last pupil. (GALLUZZI. In Museo Galileo, 2010, pp.I53-165)

The Galilean lesson was very fruitful and the attempts to develop the telescopes increased the Medicean collection in the years of Ferdinando II (I610-1670) and his brother Leopoldo (1617-1675): they organized optical competitions, acquired telescopes by the opticians Eustachio Divini and Giuseppe Campani, received lenses which were signed as works of art, and founded the first scientific academy, the Accademia del Cimento (1657-I667). 


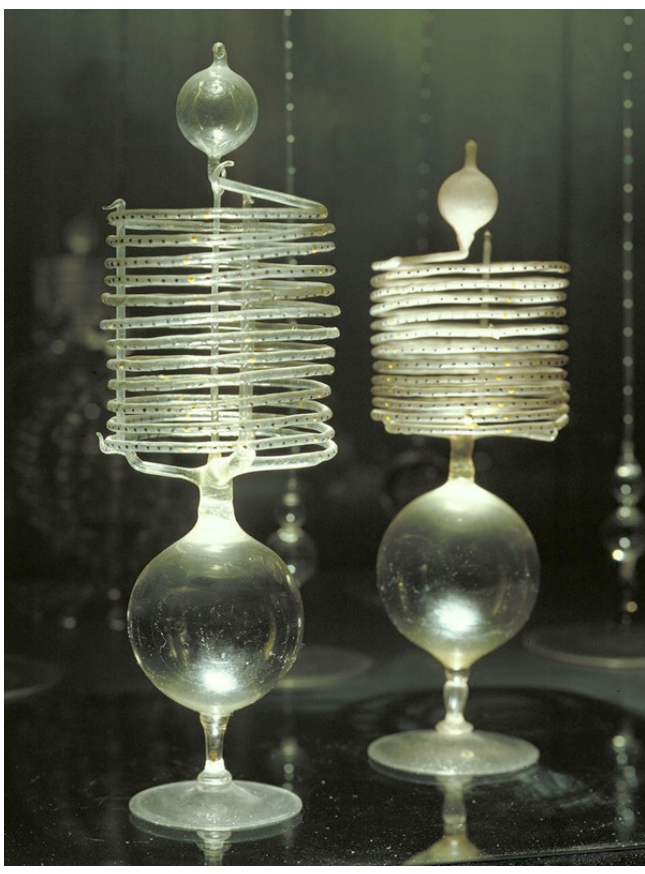

Vetri Cimento

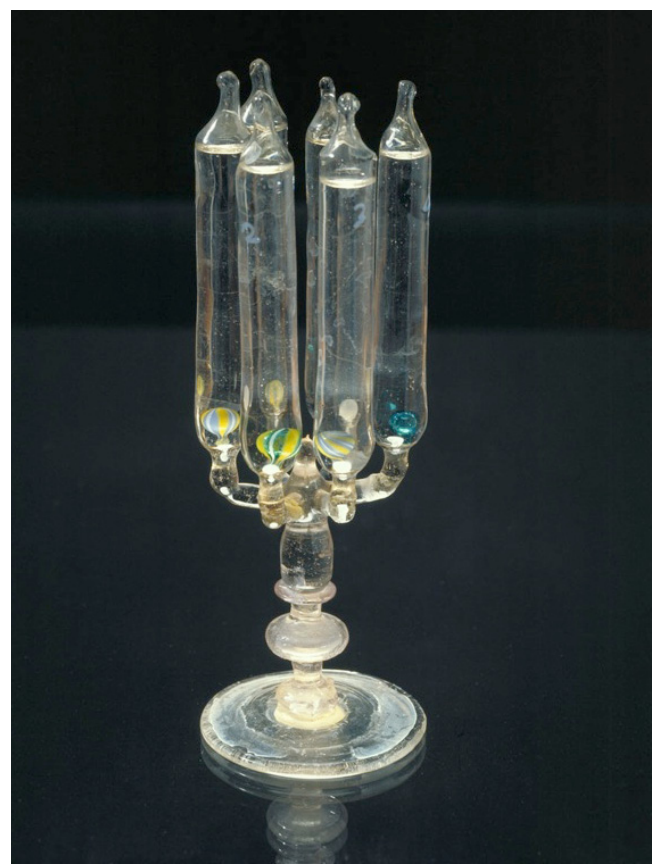

Infingardi thermometer

Ferdinando II himself was, it seems, the inventor of the thermometers called "infingardi" (slow, lazy), the "gelosissimi" fifty-degree thermometers, and the sixty-degree thermometers used for cooking eggs. (GALLUZZI, 200I).

We have to consider that Florentine seventeenth-century physical and mathematical research gave origin to four important instruments, which are the telescope, the 'occhiale', the microscope, the 'occhialino', both from Galilean research, the barometer, dated 1644, from the studies of Evangelista Torricelli, and the thermometer, born in the Accademia del Cimento.These four were then developed and perfected outside and neither in Florence nor in Italy. The Medici were aware of their importance: they sent their thermometers everywhere, organized competitions to verify the quality of the lenses and so on.

Cosimo III (1639-1723) corresponded with the workshop of Blaeu to have globes and spheres, maps and books. In 1673 he received the important new calculating machine invented by the Englishman Samuel Morland and constructed by makers Henri Sutton and Samuel Knibb from London. He also ordered a very elegant and artistic frame for the Galilean objective lens owned by Prince Leopoldo, then Cardinal, until his death. In 1677, the artist Vittorio Crosten worked it in ebony and ivory: in the centre, like a relic, was the lens, surrounded by small sculptures of the mathematical instruments existing in the Medicean collection and of the Galilean telescopes. Viviani started the celebration of Galileo, and Gian Gastone (167/-1737) erected the funerary monument to the scientist in the Basilica of Santa Croce and made it possible to move the Galileo's body to its mausoleum. 


\section{Private collections in Italy}

Not only prince collections were known between $16^{\text {th }}$ and $17^{\text {th }}$ century and not only in Florence. We can recall the museum of the physician and botanist Francesco Calzolari (I522-1609), in Verona (CERUTI, CHIOCCO, I622); the collection of Ferrante Imperato (I550-I63I) in Naples (STENDARDO, 200I), both dispersed. In the seventeenth century, Ferdinando Cospi (I606-I686) created a museum in Bologna and gave it the Senate of Bologna.

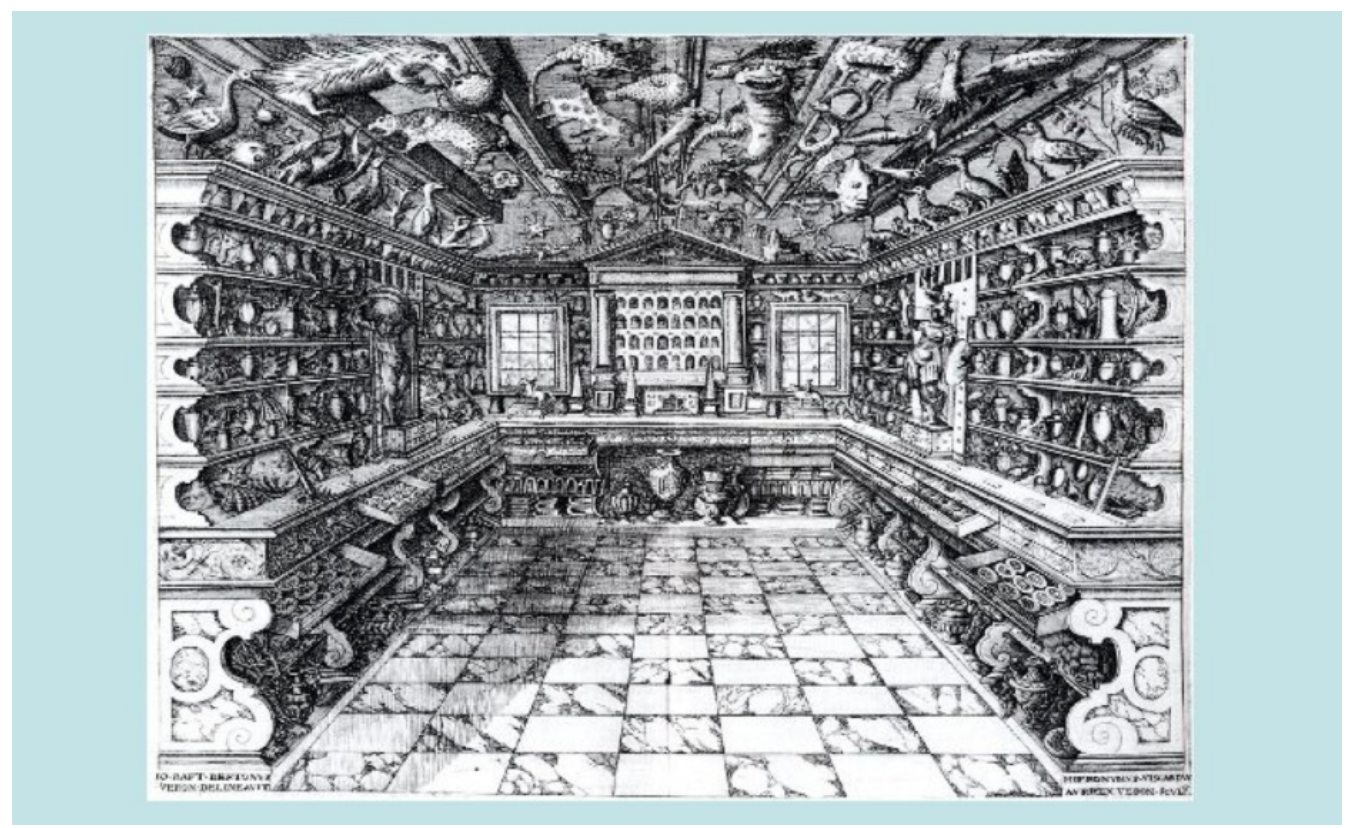

Museo Calzolari

So, it became part of the collections of the Istituto delle Scienze in Bologna and still exists (LEGATI, 1677). Another famous (and still existing) private collection was created by Manfredo Settala (1600-I680) in Milan (Museo - Galeria, 1666), and he called it a "collected gallery of knowledge". Finally, I would mention the collection created by the scientist (and Jesuit) Athanasius Kircher (I602-I680) in Rome (De Sepi, 1678; Bonanni, I709; Enciclopedismo in Roma barocca, 1986; BARTOLA, 2004), placed in the Roman College, included archaeological and naturalistic, scientific instruments, and ethnographic material.

\section{Collections in Florence between I8th and 19th century}

Coming again in Florence. After the end of the Medici age, the $18^{\text {th }}$ century Lorraine Florence separated the artistic collections from the scientific collections: the latter were placed in the new Imperial and Royal Museum of Physics and Natural History, wanted by the Grand Duke Peter Leopold of Lorraine and opened in 1775. The founding of this museum by the Lorraine dynasty represented the new development and the consideration of the material of scientific interest in Florence. In only a few years the new institution was to radically transform the order of the collections, regrouping the material of scientific interest and dividing it from the artistic in a definitive manner.

From the end of the " 60 s we have detailed information about the preparation of this new museum. Felice Fontana, who had already been named director of the institution, received scientists visiting Florence in these years (CONTARDI, 2002; MAZZOLINI, 2005). He showed the famous visitors the 
new machines of physics, explained his own discoveries, and also described the research, which he was conducting. Fontana chose old instruments from the Medici collection to create a section dedicated to scientific instruments of the Renaissance.

The celebrity of the Museum of Physics and Natural History was such that within only a few years, between the end of the 18th century and the beginning of the 19th, the references to it and descriptions of it are countless. Cited as one of the best in Europe, the Florentine Cabinet possessed an enviable collection of minerals and precious stones, of experimental apparatus, and a unique collection of wax anatomical models. (CONTARDI, 2002) ${ }^{3}$.

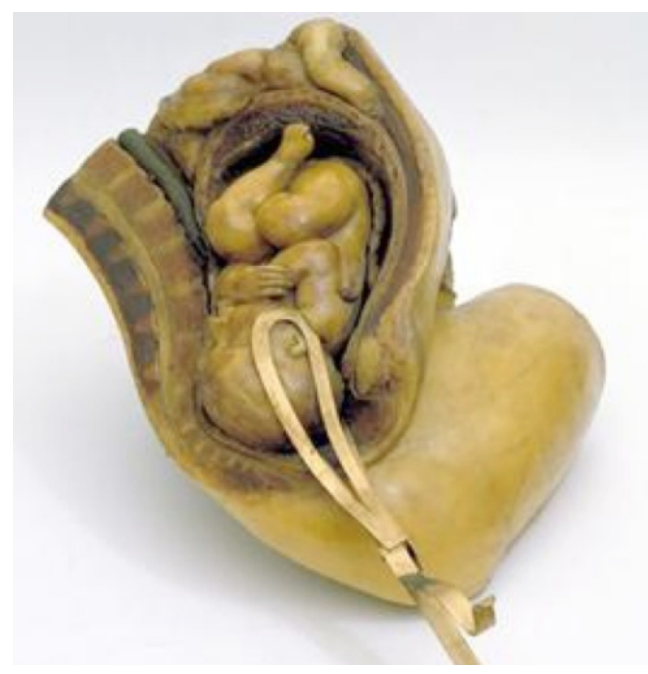

Wax Model

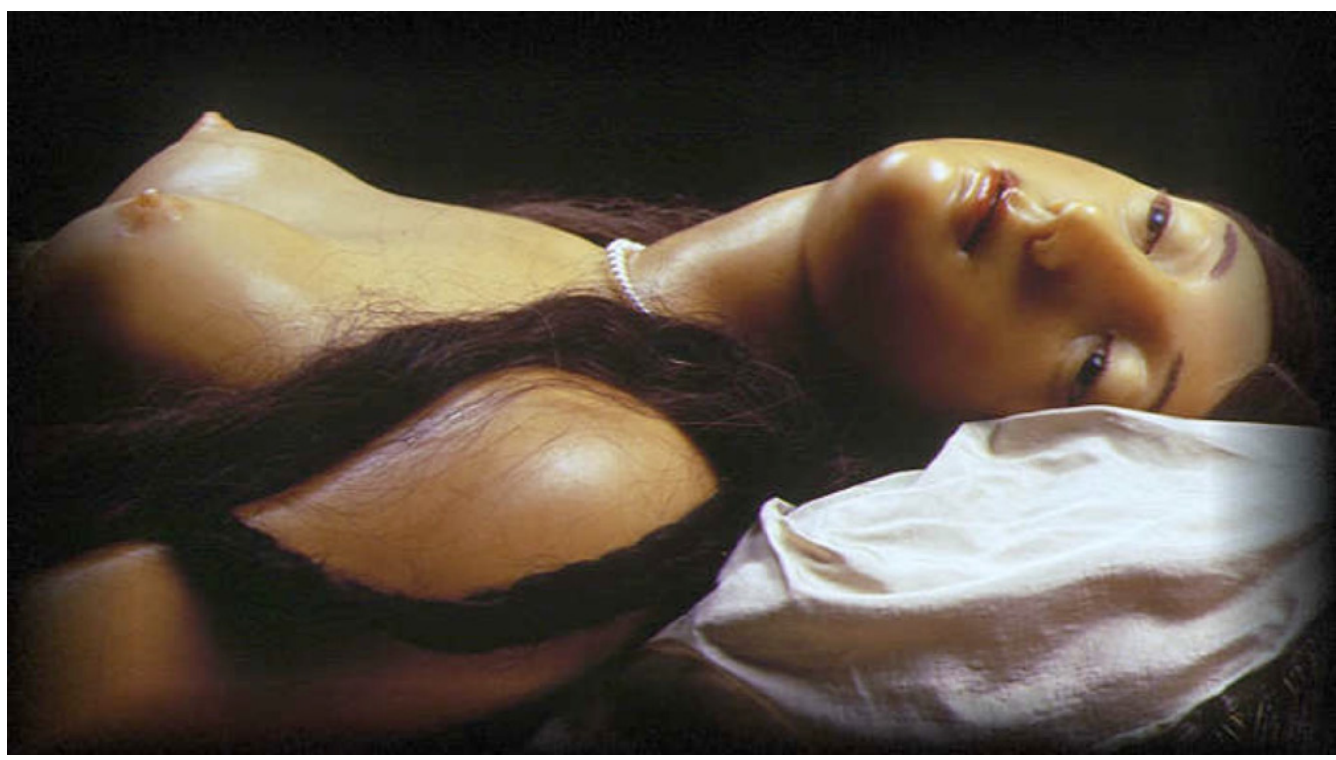

Wax Venere

3 The natural history collections constitute today the nine sections of the Museo di Storia Naturale of the University of Florence. Located in various buldings in Florence, the museum preserves more than ten millions of specimens 
In any case, this museum was not a scientific island in Florence. In fact, the cultural life in the Tuscan capital was lively: in the first half of the 18th century the arts and sciences were cultivated, and Florentine cultivated people were interested in the recent development in physics, in Italy and abroad. In that period numerous, private and public scientific collections in Florence existed, which were less famous, but not less important than the Medicean and Lorraine collections.

Private scientific collections were above all naturalistic: we can mention the large collection of shells realized by doctor Niccolò Gualtieri (Florence, 1688-1744), today dispersed, but very famous in that period; the collection of the Frenchman Jean François Baillou, Director of the Royal Florentine Gallery under Gian Gastone de' Medici in 1730, who had gathered plants, herbaria, stones and minerals, dispersed when he became Director of the Imperial Museum in Wien. Another collector was the German Philipp Stosch (Küstrin I69I-Firenze I757), informer for the English government, who lived in Florence from I73I, where he became attached to the Masonry. He collected engraved stones, medals and coins, and many manuscripts and printed books of geography, mathematics, physics and architecture. After the death of Stosch, his nephew, with the help of the archaeologist Johann Joachim Winckelmann, published the catalogues of the collection. The Vaticana Library in which they are still preserved acquired the 57I manuscripts, described in an Index codicum manuscriptorum. The marquis Riccardi bought most of the printed books, today preserved in the Riccardiana Library in Florence. The maps and plans are now at the Oesterreichische Nationalbibliothek and at the Albertina Graphische Sammlung in Wien; the precious stones in the Altes Museum in Berlin (TOTARO, 1993).

In the second half of the I8th century, Bartolomeo Mesny, a doctor and director of the "Spezieria" of the Pitti Palace, collected, like most scholars of the same period, stones, herbaria, shells, bones and so on, today dispersed.

The most important collector at that time was Giovanni Targioni Tozzetti, a great scientist and naturalist, to whom we owe very useful descriptions of Tuscany and who possessed the natural history Cabinet of the botanist Micheli. His collection was rich in herbaria, minerals and scientific manuscripts. Everything is still preserved in Florence. Giovanni Gaspero Menabuoni was another important collector. Former professor of Italian in Paris, librarian at Palazzo Pitti in Florence, he had collected paintings he had bought in Paris, and naturalistic collections.

We find an important scientific attraction in Florence, in the second half of the 18th century: the cabinet of George Clavering, third Earl of Cowper. Lord Cowper organized his scientific laboratory, boasting some 400 instruments, physics machines and important books, in his house in via Ghibellina, near the church of Santa Croce, but he lived in a beautiful villa on the hill of Fiesole, now called Villa Palmieri. The curator of the scientific apparatus was Alfonso Guadagni (I722-I80I), an experimental physicist, and Professor of Physics at Pisa University. After the death of Lord Cowper ( I789), his collection was bought by the Cardinal Archbishop of Bologna, Andrea Gioannetti, for the Science Institute and Physics Museum of Bologna, where it is presently preserved. (DRAGONI, 1994)

\section{Public and private collections in Florence in 19th century}

The Imperial and Royal Museum of Physics and Natural History during the 19th century is crucial to understand the Florentine cultural and scientific context. The institution was one of the core areas of research and teaching activities aimed at the dissemination of the scientific knowledge. This knowledge, debates, publications and lectures came to be the scientific and cultural background not only the city but throughout the Grand Duchy. 


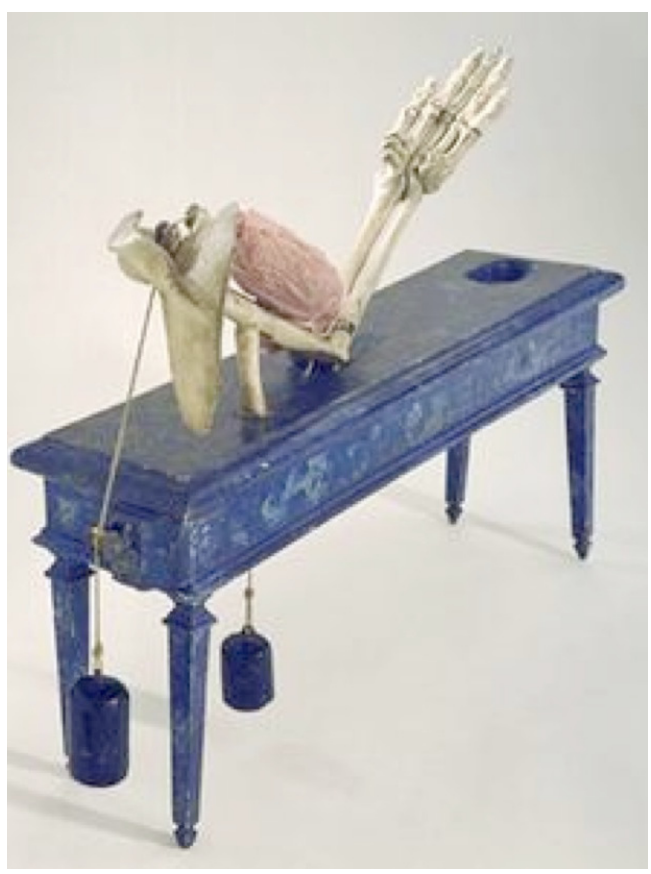

Braccio Leva
When Vincenzo Antinori became director of the Museum, it had more than 50 years of life, had become a reference point for specialists and scholars, known by illustrious visitors and amateurs (CONTARDI, 2002).

Rich in collections of instruments either constructed inside the museum or acquired abroad, and in natural specimens from foreign countries, the museum had also a huge collection of wax anatomical models constructed in the workshop inside the museum, and was devoted to the preservation of the scientific patrimony before collected by the Medici family.

After Pietro Leopoldo, who left Tuscany in 1790, after the period of the French dominance and difficult situations both political and social, the museum was less active and known.

Vincenzo Antinori found in 1829 an institution which needed a new impulse to afford a new development and confront the changes of the new century.

A brilliant scholar of Physics and Mathematics, and a passionate popularizer of the work of Galileo,Antinori was in close contact with the leaders of the Tuscan moderates. He represents a figure of peculiar interest in the scientific context in Tuscany and his appointment is of particular significance.

The new Grand Duke, Leopoldo II, together with the group of intellectuals living in Florence, favoured this program. These persons were: Gian Pietro Vieusseux, who had founded the Gabinetto Scientifico e Letterario in 1820 and, in the year after, the journal L'Antologia in which scientists, humanists, historians and so on published their essays; Cosimo Ridolfi, who founded in the same year 1829 the Cassa di Risparmio to preserve the money of the poor people, who created in his Villa of Meleto a school to prepare workers in agriculture, who directed the very important Accademia dei Georgofili, founded in 1753, and involved in modernizing the agricultural studies.

Other important names and institutions in these same years of the 19th century were the Osservatorio Ximeniano, founded in 1756 by the Jesuit Leonardo Ximenes, and then directed by the Scolopi, among them Giovanni Inghirami, astronomer and cartographer, who wrote in 1830 the first geometric map of Tuscany (MINIATI, 2009).

In this 'Florence of science' arrived the physicist Leopoldo Nobili who invented new and innovative magnetic instruments and allowed a big improvement of the studies on the electromagnetism. Also the astronomer and optician Giovan Battista Amici lived in Florence: he constructed microscopes and lenses and created a mechanical laboratory at the origin of the future Florentine industry of precision instruments Officine Galileo.

Antinori himself wanted the talented scientists Nobili and Amici as part of the Museum of Physics. He urged the Florentine Court to the creation of 
courses and lessons, and in general to a didactical activity within the Museum. The project was successful, and in 1833 three chairs were assigned to as many teachers: Physics to Leopoldo Nobili, Comparative Anatomy and Zoology to Gaspero Mazzi, Mineralogy and Geology to Filippo Nesti. To improve the collections, the teachers report also either possible purchases, or obsolete instruments.

Antinori emphasized the importance of the Museum and declared that its cultural heritage had to be available to all subjects. He endorsed the idea of a pedagogy capable of affecting the heart and mind of the pupils, and emphasized the educational value of science: thanks to it, young people can understand the relationships between different phenomena, and develop the spirit of observation.

As scientist and director of the Museum,Antinori choose a behaviour coherent with his view of a public-minded science. He reorganized the galleries in the Museum of Physics: the objects were scientifically and historically arranged, according to his idea of an educational institution.(CONTARDI, MINIATI, 20 I I)

Particularly interesting is the criterion proposed by Antinori in order to display the collections of scientific instruments and machines to visitors. His policy follows a precisely historical order: scientific instruments and machines should be arranged according to the historical periods in which those scientific theories were discovered.The historical order does not concern the date of the manufacture of instruments, because Antinori is not interested in the history of the collection. Rather, he resorts to instruments in order to illustrate the most relevant discoveries in the field of physics, and the development of the discipline. This is a very important point. According to Antinori, the history of science is the history of the discipline. Following the path created by the Florentine scientist, the visitors of the scientific museum must be enabled to grasp the several phases of physics. They can learn step by step the development of a science inasmuch as they become aware of the instruments employed in it.

The concrete arrangement of scientific instruments in the Museum

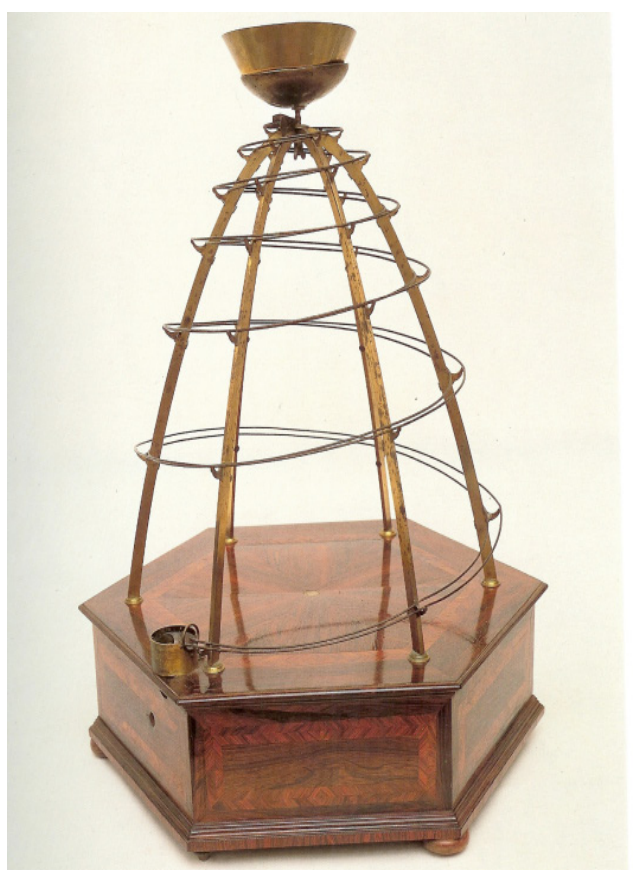

Caduta Gravi Parabola must be the mirror of the historical and conceptual path of the discipline, and the visitors can understand the progress of physics and its discoveries because they are chronologically and consecutively displayed.

Obviously, the underpinning conviction was Antinori's idea of the history of science: the idea of a progressive, continuous increase of knowledge, conductive to a full disclosure of the secrets of the natural world.

In the twenties the Museum was rich in physics instruments, which amounted to over 900: scales and thermometers, barometers and pneumatics machines, instruments for experiments on electricity, telescopes and microscopes and various optical devices.

There were also the very precious instruments coming from the 
Medici collections: astrolabes and quadrants, sectors and dividers, the Galileo's relics and the glasses of the Accademia del Cimento. The collection is preserved now at the Museo Galileo-Istituto e Museo di Storia della Scienza in Florence (MINIATI, I99I; CAMEROTA, 20I0).

The astronomical observatory, constructed in the 18th century and completed in 1784, had important clocks and telescopes. And also the natural history collections were rich and important: as Fausto Barbagli writes, they were oriented toward the naturalistic analysis of Tuscany, and this analysis put the theoretical knowledge to good use via exploitation of the natural resources of the territory (BARBAGLI, 2009).

Antinori tried to improve the collections, both physical and natural. Under the impulse of the Grand Duke Leopold II, new exploratory travels were promoted and new interesting specimens were collected. Modern machines were acquired for the Cabinet of Physics, above all thanks to the Physicist Leopoldo Nobili and to the astronomer and optician Giovan Battista Amici.

Nobili (L'eredità scientifica, 1984; Leopoldo Nobili, 1984) was famous for his studies on electromagnetism and was well known by Antinori, who bought for the museum a galvanometer (an instruments invented by Nobili and offered during his visit to Florence in 1830). The year after he was involved in the riots in Reggio Emilia, was exiled in Marsiglia and then in Paris, and finally went in Tuscany. Nobili was strictly connected with Gian Pietro Vieusseux, and Antinori obtained his appointment as professor of Physics at the Museum, where the scientist worked actively and promoted an experimental activity.

Amici (TAROZZI, 1988; MESCHIARI, 20I4) from Modena was called in the same $183 \mathrm{I}$ to be astronomer at the Florentine Specola, the observatory tower constructed by Peter Leopold. Amici worked for the museum, constructed telescopes and lenses, very precise and successful microscopes, and worked with the wax modeller Luigi Calamai to realize wax botanical models of specimens observed with his microscopes.

The name of Galileo was often recalled in the years of Antinori direction. He, together with Amici, Ridolfi, and others, promoted the Meetings of Italian Scientists, based, as Barbagli says, on the national congresses held for several years in various northern European states. The idea of this kind of meetings comes from the Prince Carlo Luciano Bonaparte, who «recognized the Grand Duchy of Tuscany as the most suitable place to host such an event, aware of the personal scientific interests of the enlightened ruler, who had been conferred the title of Member of the Royal Academy of London» (BARBAGLI, 2009). The first Meeting was in Pisa in 1839, the third in Florence in 1841. For this third, the Tribune of Galileo was erected inside the Museum of Physics, as a temple to the memory

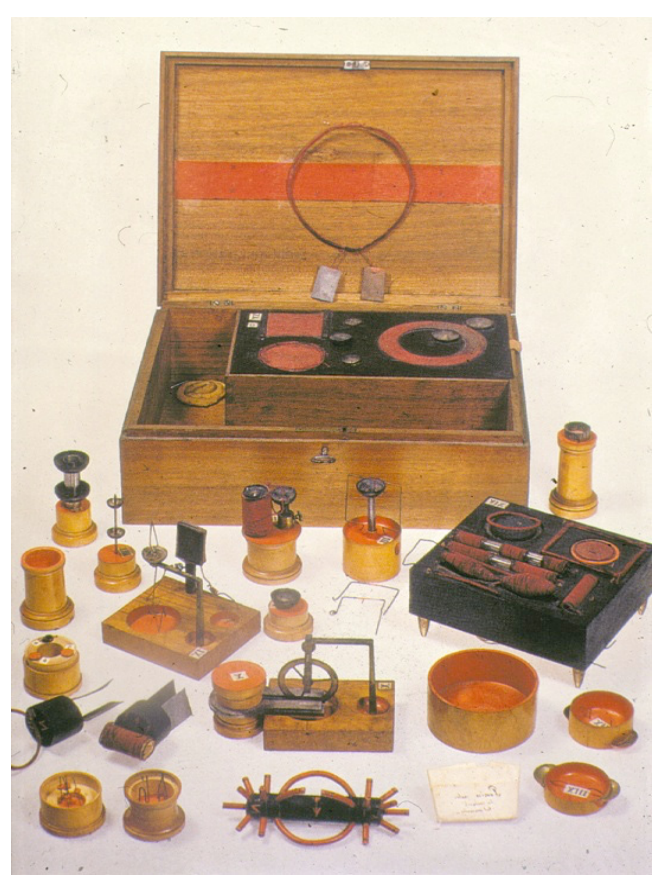

Nobili of Galileo and his discoveries (Idem). 


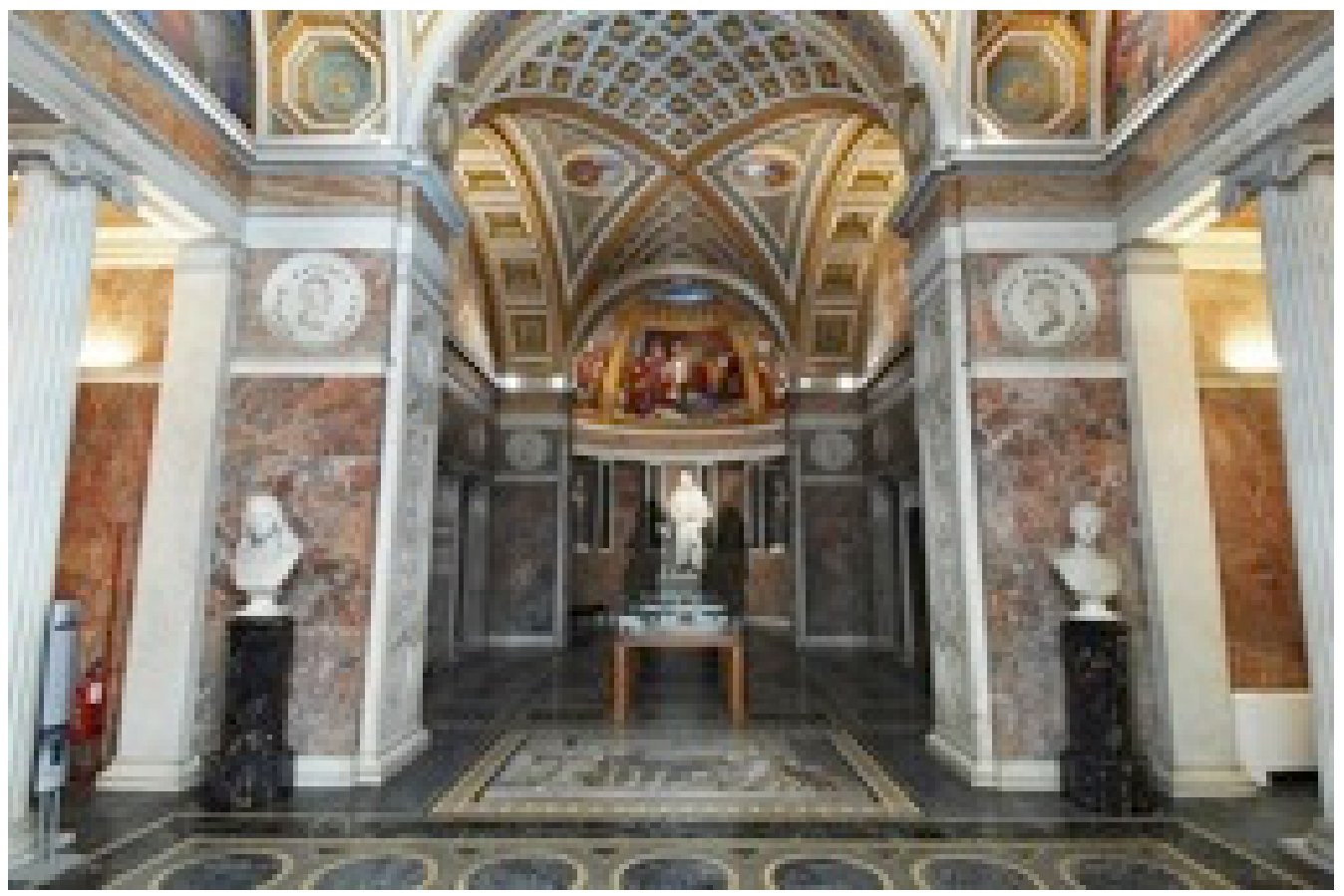

Tribuna

Antinori conceived the iconographic project while the architect Giuseppe Martelli was entrusted to realize the architectural project. This temple was provided with frescoed lunettes showing various moments of the scientific activity of Galileo, of the Accademia del Cimento and, in general, of the scientific research from Leonardo da Vinci to Alessandro Volta.Various stuccos and bas-reliefs portray astronomical discoveries and scientific instruments, while medallions offer portraits of important persons in sciences and their developments.

Everybody admired the Tribune, in which instruments from Galileo and from the Accademia del Cimento were on show in special display cases.Astrolabes and in general Renaissance instruments from the Medicean collection were also there, and the imposing statue of Galileo made by the sculptor Aristodemo Costoli was at the end of the Tribune. In some rooms around the Tribune Antinori settled the old Physics cabinet.

The annexation of Tuscany to the Kingdom of Italy had an impact even on the Museum of Physics and its collections. Vincenzo Antinori, director since 1829, resigned in 1860 and was succeeded by Cosimo Ridolfi (I794-1865). At the same time, owing to Tuscany's new status and the establishment of the new Institute for Higher Education (Istituto di Studi Superiori) in Florence, the Museum was incorporated into the Institute as its Physical and Natural Sciences Department and thus placed under ministerial authority and supervision, (CONTARDI, 2009, BARBAGLI, 2009).

Ridolfi pursued the work begun by Antinori. The Museum compiled new inventories of its collections, gradually recording additions and new acquisitions. Ridolfi shared his predecessor's belief in education as essential for training generations to act for the good of the State. He put this belief into practice not only in the Museum, but also by establishing schools that would produce knowledgeable farmers, emancipated from ignorance and poverty, thanks to the invention of modern farming machines.

In Ridolfi's five years as director, his scientific interests-focused on electromagnetism and the popularization of science-fostered the expansion of 
significant sections of the Museum. Gaps in the physics collection, for example, were filled by the acquisition of electromagnetic machines, tubes, and demonstration instruments, mostly obtained abroad (MINIATI, 2009).

At Ridolfi's death, Filippo Parlatore (I816-1877), a famous botanist and traveler, was appointed "Acting Director and Chairman of Physical and Natural Sciences Department of the Institute for Higher Education." He occupied both positions for few months, when Carlo Matteucci (I8I I- I868), Minister of Education since I862, also became Museum director (MINIATI, 20I2).

Although rather brief, Matteucci's tenure was significant for the value he attached to the Museum as keeper of the glorious memories of the Italian scientific tradition. The conservation of Galileo's instruments, the glass instruments of the Accademia del Cimento, and the Renaissance measuring devices "entitled" Florence to the privilege of hosting institutions dedicated to the history of science. At Matteucci's death, Parlatore was reappointed director, and he remained at the head of the Museum until 1877, assisted by Ferdinando Meucci (1823-1893), who played a vital role in arranging and curating the collections.

Meucci joined the Museum in 1844 as a contract worker in the Archive. In the 1870s, he recommended acquisitions, promoted restoration work, and kept constant watch over the Museum's affairs and the condition of its collections.

In 1872, officials decided to transfer some of the natural-history collections to Piazza San Marco, where the Institute's administrative offices were located.The Schools of Physics, Chemistry, Physiology, and Anthropology, together with their laboratories, had already moved. The Museum's former building continued to house the old physical and astronomical instruments and the zoological and botanical collections. The Museum was open to the public, with free entrance, only on Tuesdays, Thursdays, and Saturdays.

Also in 1872, thanks to the efforts of the astronomer Giovanni Battista Donati, the Observatory moved to its new facility at Arcetri. From this hilltop location, one could perform astronomical observations without the inconvenience of restricted horizons and ground vibrations. In 1874, Parlatore decided the reorganization of the collections, with the distinction between teaching materials for the professorships and old artifacts unsuited for educational purposes. He defined the Museum's new profile: the institution effectively became a Museum of Ancient Instruments, a repository clearly distinct from the scientific laboratory of the Lorraine period.

This transformation was confirmed in 1875 by Parlatore himself, who suggested small labels for every object with the exact listing of its provenance and date, its inventory number, and all the information useful for its full identification. That same year, the astronomical observatory and the meteorological observatory, which had remained in the main building, were separated institutionally as well.

Between 1876 and 1877, after an eleven-month restoration, Santucci's large armillary sphere was added to the Museum's holdings. The "battered" sphere had been cleaned with reagents, and only the stand and the external sphere had been "refurbished." In his reports on the work performed, Meucci proudly described as a total novelty the fact that the armillae had not been repainted, but that the original had been recovered exclusively thanks to cleaning. Meucci also proposed the acquisition, immediately approved, of a very old Arab celestial globe, and of a small group of instruments by Giovan Battista Amici offered to the Museum.

Over the years, the Museum often participated in shows in Italy and abroad, sending large numbers of precious objects every time. After Parlatore's 
death, Meucci became effectively responsible for all of the Museum's activities, although the official head was the Dean of the Physical and Natural Sciences Department of the Royal Institute of Higher Education.

Meucci's work at the Museum involved an intensive daily routine of curating the collections, commissioning restorations, proposing new acquisitions, and receiving gifts. These gifts, as well as other accessions and work programs completed, were often mentioned by Meucci in the letters and reports regularly submitted, in his capacity as curator of the collections, to the Institute for Higher Education, which had authority over the Museum.

One of the operations that involved Meucci in delicate negotiations was the purchase of the Galilean clock built by Eustachio Porcellotti. The Florentine clock-maker copied the recently rediscovered drawing by Vincenzo Galilei and Vincenzo Viviani. In 1860, he built an iron model of the clock, which the Museum acquired. Porcellotti then continued to study the documents until he was able to produce an actual replica of the clock, complete in every detail. He offered it to the Museum. ${ }^{4} \mathrm{~A}$ few years later, the clock-maker's services were requested again for the production of a second copy of the clock, which was delivered to the Museum and forwarded to the Science and Art Department in South Kensington, London, which had asked for it.

In the same period, applying principles inconceivable today, Meucci sought to put ancient and disused devices in operation again, irrespective of the period to which they belonged and their status as "historical objects." The Museum made a major addition to its holdings by purchasing the instruments formerly owned by the scientist Vincenzo Viviani, Galileo's last disciple.Viviani had died in 1703, leaving his possessions to the Santa Maria Nuova Hospital (Arcispedale) in Florence. Meucci catalogued the material and picked the most significant items. Along with the Viviani instruments, the Museum accessioned globes and spheres preserved in the Hospital library, for which Antonio Roiti (I843-192I), professor of physics at the Royal Institute of Higher Education and Dean of the Science Department, had compiled a list in the wake of Meucci's inventory ${ }^{5}$. Meucci did not live to see these new acquisitions, for he died in 1893. He had worked unstintingly until his final years, and the profile of the Museum of Ancient Instruments was unquestionably his creation.

Despite the Museum's strong commitment and its participation in national and international events where its instruments had been admired by many visitors, conditions at the Museum in the late nineteenth century were not ideal. Meucci had often lamented the fact that the Tribuna would flood "with every downpour," the windows were dirty, and the air was so cold as to "cause shriveled visitors to flee." He could rely on only one employee - and there were more than a thousand objects to preserve and curate.

The truth is that interest in historical and obsolete instruments had faded considerably. By contrast to the visibility of the Medici and Lorraine collections achieved in the London and Paris exhibitions, the same objects in the Florence Museum were becoming ever more marginal. While natural-history collections were also serving an educational purpose in the relevant university-level

4 In November 1878, Meucci asked for permission to purchase it. In his request, he recounted the history of the instrument's construction, explained its importance, and stressed its connection with the Museum's collection of historic artifacts. It thus fell to Meucci to publicize the acquisition, both among specialists and through articles for the general public, which appeared in the Florence daily La Nazione.

5 To this day, the Museo Galileo's current inventory identifies these instruments by their numbers in the Roiti list. 
institutions, the instruments remaining in the Specola seemed fated to slide into oblivion. The deterioration of so valuable a heritage would not become a public issue until the 1920 s. In a report to the National Congress of the Society for the History of Medical and Natural Sciences in Bologna in 1922 , Andrea Corsini (1875-196I) denounced the shabby condition of the collections of old instruments, hidden away in basements when no longer used, covered in dust and forgotten. His presentation triggered a revival of interest that shortly led to the formation of a "Group for the protection of the national scientific heritage" in Florence. Besides Corsini himself, members included leading cultural figures of the day such as the physicist Antonio Garbasso and Prince Piero Ginori Conti. The Group established the Institute for the History of Science, with offices at the School of Medicine in Via degli Alfani. Officially recognized in 1927 (BAROCELLI, BUCCIANTINI, I990; BUCCIANTINI, 20I2) the Institute was incorporated into the University with the task of gathering, cataloguing, and restoring hitherto scattered historical scientific apparatuses, which would then be collected and preserved. The Santa Maria Nuova Hospital-which had previously sold the objects from the Viviani bequest to the Museum of Ancient Instruments - immediately handed over a large part of its historical holdings to the newborn Institute. They included the set of eighteenth-century surgical instruments designed by Giovanni Alessandro Brambilla and fabricated by the cutler Joseph Malliard, and some eighteenth-century mortars and old microscopes no longer in use.

These accessions constituted the first nucleus of material to which were gradually added the other objects that now form the Museo Galileo's collections.

\section{Other collections in 19th century Florence and elsewhere in Italy}

In the middle of the $19^{\text {th }}$ century, the Grand Duke Leopold II (I7971870) inaugurated in Florence the technical School, which should provide a technical and scientific preparation to new professional figures in the fields of agriculture, arts, crafts and industry. The mathematician Filippo Corridi (I8061877) was is Director until 1859. He acquired un enormous amount of didactic apparatus, natural specimen, and scientific books. The school became an efficient polytechnic institute, growing during the years, thanks to the high quality of the teachers, which increased the number of the students. The school exists today and the historical collections are preserved by the Fondazione Scienza e Tecnica, which was born in 1987 to promote scientific an technical culture, and preserve this unique patrimony (BRENNI, 2009; GIATTI, LOTTI, 2006).

In the same second half of the 19th century other collectors lived in Florence: Herbert Percy Horne, who collected Renaissance paintings, furniture and scientific instruments, which were entailed to the Italian State, when he died in 1916 (BERTANI, 200 I); Frederick Stibbert, painter and traveller, collected arms, ceramics, clocks and other objects, and his palace, with his complete collection is now a public museum (DI MARCO, 2008; FUCHS, DI MARCO, 2003); Jean Louis Carrand, from Lyon, had a large collection of ivories, fabrics, jewelleries and also of a small group of scientific instruments, and left it to the Florentine Museo Nazionale del Bargello. (Barocchi, Bertelà 1989; Miniati 199I). 


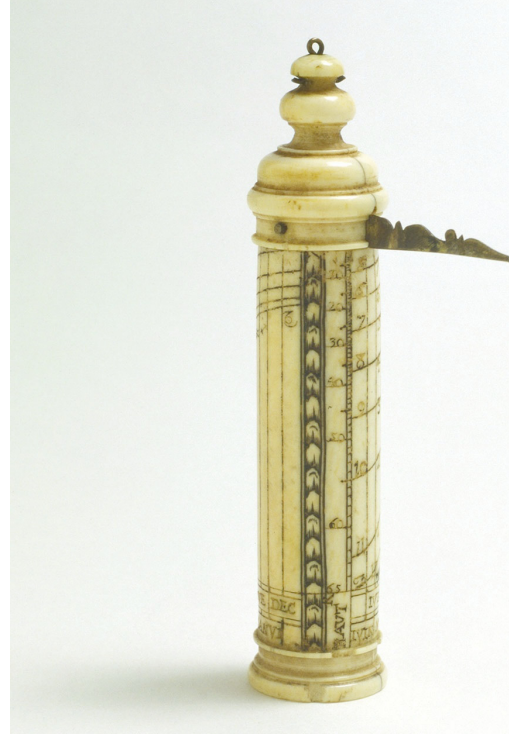

Cosmometro Bargello Recto

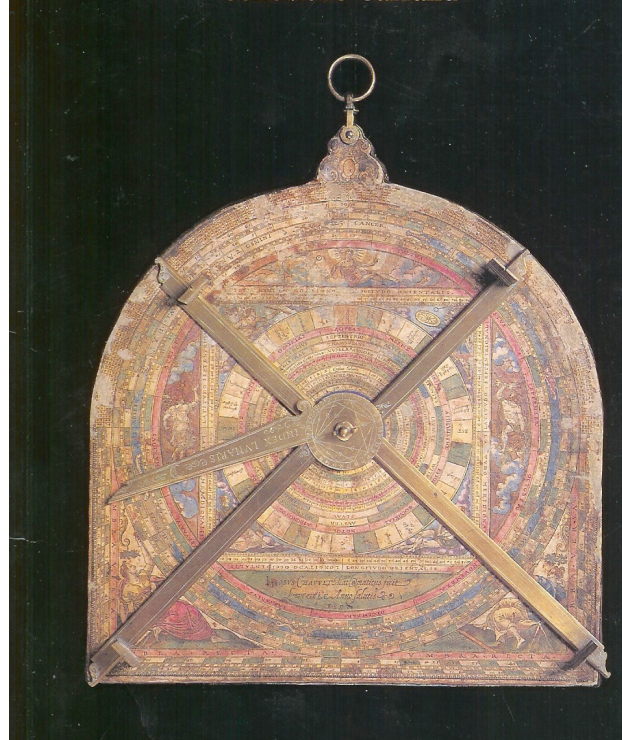

Orologio Solare Horne

Just a short mention to Italy: the brothers Fausto and Giuseppe Bagatti Valsecchi, in Milan, created in the nineteenth century a house-museum (which still exists) in the center of the city. The museum (now in public ownership) has a big quantity of furniture, paintings, and also precious scientific instruments (MINIATI, 2003). In Milan there is also the Museo Poldi Pezzoli, which originates from the collection of Gian Giacomo Poldi Pezzoli (I822-1879). It was enlarged in the years thanks to donations: Bruno Falck (1973) has endowed it with precious watches and clocks, and Piero Portaluppi (1978), with sundials (Brusa, Gregorietti, Tomba 1981).

Let me add a short reference to Giorgio Roster (1843-1927), doctor and expert in meteorology, and famous for his research on photography and botany. Between 1895 and 1896 he created the Giardino dell'Ottonella, in the Island of Elba, with more than 700 exemplars of exotic plants, which is still existing ${ }^{6}$. (BERNARCCHINI, 2007)

\section{From the Istituto e Museo di Storia della Scienza to the Museo Galileo}

In 1930 the Institute for the History of science became Institute with museum, because it was moved to the new building not far from the Uffizi Gallery, in which it is located today. It received instruments from La Specola, that is the Medicis and Lorraine collections. Andrea Corsini was named its first director and he organized the galleries of the material. After few years, in 1942, Maria Luisa Bonelli (1917-198I) was named Keeper of the Institute and Museum of the History of Science. Her knowledge of the Museum and scientific instruments grew "on the job," day after day, in step with her work in progress. She found crucial support - to which she repeatedly paid tribute-in Pietro Pagnini (1875-1955), an engineer deeply versed in scientific instruments and a close collaborator of the Museum.(BERETTA, 20I2) $)^{7}$ After the war and the massive reconstruction effort, the catalogue prepared by Pagnini, who wrote the

6 Roster collected also minerals, and thousands of them are today preserved at the Museo di Mineralogia of the University of Florence. 
technical descriptions of the instruments, and by Bonelli, as Keeper, marked a milestone toward establishing the Museum's visibility far beyond the city boundaries.

Although Andrea Corsini was officially Director, Maria Luisa Bonelli personally conducted an intensive correspondence and maintained contacts at various levels with other Italian and international institutions, private collectors, specialists, scholars, and enthusiasts. She did not have a scientific background but was trained in the humanities. She saw the Museum as a treasure-house of memories to protect, showcase, and preserve. As a result, when she succeeded Corsini as Director in 196I, she set out to reorganize the exhibits in a less celebratory and more historical manner. She was convinced at the time-and would remain so all her life- that the Museum was unique and that its strength lay precisely in this status. The Museum was the world's sole depository of the Medici and Lorraine collections, of the relics of Galileo and the Accademia del Cimento, of instruments that had always belonged to Florence. Every object had a history that could be reconstructed, each could be reconnected to the life of the Court, to episodes in the city's history, and to the history of collecting. Her training in the humanities impelled her to study documentary sources and conduct archival research that would enable her to identify the objects and trace their history back to their origins.

Appointed Honorary Inspector for the research and conservation of historical documents in science and technology, first for the Province of Florence, then for all of Italy, Bonelli scoured the country for material to salvage and restore. In some cases, she managed not only to recover instruments and artifacts, but also to transfer them to the Florence Museum. As Director, Maria Luisa Bonelli had her distinctive working method, imbued with uncommon energy and liveliness. She wrote many letters; she sent articles to local newspapers picking fights with journalists who did not hold the Museum in proper esteem; she published other articles in specialized journals, in a constant effort to raise awareness of her institution, to make it appreciated, and to advertise the wonders it contained. Her essays - at times just a few pages long, always easy to readwere designed to familiarize a rather diverse public with scientific instruments and their significance.

The 1966 flood seemed to spell the end of the institution, which was so close to the Arno and so severely struck when the river overflowed. However, thanks to the Director's network of contacts, and also thanks to the awareness of the Museum's existence even abroad, significant help-both financial and physical-arrived from all over the world. People came to dig and to assist in other ways. They were soon inducted into the "Academy of the Muddied Ones," which Bonelli herself, recently married to the astronomer Guglielmo Righini, had just founded.

In her tireless manner, Bonelli Righini saw the catastrophe caused by the flood as an opportunity to revitalize the institution and establish further ties with specialists and technical experts. These contacts were aimed at launching a collective effort to salvage, restructure, and renovate the Museum that Corsini had created slightly over thirty years earlier. Thus, the event that could have terminated the Museum of the History of Science instead marked its new beginning and thorough transformation.

The Museum reopened with a temporary layout in 1968, and the new installation was completed in 1976.

The first floor still housed the Medici collection: cases from the previous installation were flanked by new cases with frames made of brass or other me- 
tals. The cases for the Cimento glassware were fitted with sliding glass doors to minimize vibrations and ensure a tighter closing. The new set-up also included the cases from the Lorraine period. One series, made of painted green wood, was placed along one of the walls in the cosmography room to display astrolabes and quadrants. Another series, made of elegant marbled wood, was installed in the optics room to house a large array of microscopes, kaleidoscopes, and stereoscopic viewers. In the large mechanics room, a reproduction of the lunette in the Tribuna di Galileo depicting the experiment of the inclined plane was placed above the model of that instrument and the entire space was filled with machines large and small, unprotected and ready to be set in motion so as to offer practical demonstrations to visitors.

The second floor was entirely new in every way: visitors were greeted in the first room with the muted sound of classical music, the wall-to-wall beige carpeting of the entire second floor muffled the footsteps and, together with the warm diffuse light, immediately created an elegant, soothing, and captivating atmosphere.

Just as the first floor was primarily devoted to the Medici collection, so the second floor housed the Lorraine collection, largely salvaged from the flood, restored, and made viewable again.

But the first room of the second floor was different. Called the "Book-Instrument Room," it exhibited instruments, mostly from the Medici collection, accompanied by early texts that illustrated their functions or recalled their original purpose. It was, in a sense, a presentation of the Institute and Museum of the History of Science: texts and objects interacted, because instruments did not "speak" without the texts that explained them, and because only bibliographical research-i.e., investigations of printed sources-allowed a full reading of the instruments on view. The room exemplified the "museum to browse" often mentioned by Bonelli, a museum that would resemble an early scientific book, offering the subtle and persistent pleasure that only original documents can give. (MINIATI, 20I2)

The ten rooms of the second floor were occupied not only by the salvaged Lorraine instruments, but also by the precious library of old books from the Istituto di Fisica (Physics Institute), deposited many years previously at the Museum. On the ground floor, where she had installed the secretarial office and the modern library, she had refurbished the modest pied-à-terre that she had been using even before the flood.

The ground floor also housed the chemistry collections, the pharmaceutical jars, and the reconstruction of an alchemical laboratory complete with retorts, stills, and a crocodile suspended from the ceiling. Other objects included weights and measures from different periods, scales and steelyards, and a few clock mechanisms. The fine collection of vintage bicycles completed the ground-floor displays ${ }^{8}$.

The third floor-partly occupied at the time by the Deputazione di Storia Patria per la Toscana (a Tuscan history commission)—was made accessible to visitors. In October 1977, a room was set up for screening slideshows on the history of the collections and documentaries on the most complex instruments. A second room was occupied by the planetarium built by Officine Galileo and

8 Over the years, the ground floor was enhanced with other exhibit themes. The basement housed the teatrini (mini-theaters) and a section on Leonardo. Other enhancements included a laser used for teaching purposes to demonstrate the calculation of the Earth-Moon distance, holograms produced by the Istituto Nazionale di Ottica (National Optics Institute), and some old looms, acquired by the Director from a nuns' convent near Assisi. 
donated to the Museum by the Tourism Office in 1978. Here, astronomers from the Arcetri Observatory gave lectures on their field for classes from all grades. The roof terrace housed, since 195I, the Targioni Tozzetti mineral collection deposited by the Mineralogy Institute of the University of Florence. It was also used for temporary exhibits, congresses, and dinners held by societies that applied for permission-providing additional revenue for the Museum.

In 1976, the Director founded Annali dell'Istituto e Museo di Storia della Scienza, a semi-annual journal primarily focused on scientific instruments, with contributions by Italian and foreign scholars. In the same years, the Museum prepared typewritten guides in four languages that visitors could borrow during their tour. It also issued a series of booklets on "book-instrument" topics. Each title was edited by a specialist and dedicated to a specific device, with a description of its history and use. Some booklets were even accompanied by replicas of the objects that were made with ordinary materials but worked perfectly. ${ }^{9}$

In the late 1970s, the large Medici exhibitions promoted by the Council of Europe under the title of "Florence and the Tuscany of the Medici in Sixteenth-Century Europe" offered a major opportunity for the Museum. Starting in March 1980, it hosted the section on "Astrology, Magic, and Alchemy in the Florentine and European Renaissance," installed on the roof terrace. (ZAMBELLI, 1980) ${ }^{10}$ The many visitors who flocked to Florence in those months had occasion to discover the Museum, whose attendance rate began to rise significantly.

In 1979, Maria Luisa Righini Bonelli was awarded by the Sarton Medal. She was the first Italian to receive the prestigious prize, which enhanced the worldwide status of studies and research on historical scientific instruments. Unfortunately in December 1981, she died after a long illness, and the Rector of the University of Florence, acting on the proposal of the Museum's Board, appointed Paolo Galluzzi to succeed her as Director.A university lecturer, Galluzzi was already a member of the editorial board of Annali dell'Istituto e Museo di Storia della Scienza.

There was no time to take a break. From one day to the next, we" were all involved in organizing a major event in which the Museum was entrusted with a leading role: the 350th anniversary of Galileo's Dialogue Concerning the Two ChiefWorld Systems (1632). The Institute held an international conference that traveled between the three cities associated with Galileo: Pisa, Padua, and Florence (GALLUZZI, 1983). ${ }^{12}$ Various side events were arranged for scholars including, of course, a tour of the Museum, and special publications were produced. Not all the scholars - many of whom came from abroad-had already visited the Museum. The conference therefore offered a fresh opportunity to promote the Museum, rearranged for the occasion and chosen as the venue for several of the side events.

Also in 1983, the Museum began to restructure some of its exhibition rooms. At the same time, the Museum started to hold temporary shows again. In 1985, with the help of specialists and scholars-often volunteering their ser-

9 For example, L'orologio solare; L'orologio notturno. Other booklets containing instrument models were devoted to Galileo's astrolabe, Galileo's drawing compass, anamorphoses, and the "slothful thermometer" (termometro infingardo) of the Accademia del Cimento.

10 The section was curated by the Professor Paola Zambelli.

I I I arrived at the museum in 1979 and remained there until retirement. My title at the time was Scientific Secretary in charge of research and studies on the documents preserved in the historical archive. Increasingly, however, I acted as Curator of the Museum's scientific instruments until my eventual appointment as Deputy Director.

12 The volume of the proceedings opened with an "informal” reminiscence of Maria Luisa Righini Bonelli by I. Bernard Cohen on behalf of the community of historians of science. 
vices as friends - we launched what became an annual program of small exhibits on our premises devoted to instruments usually not on display, to restored items, or to collections from other museums. In parallel, we mounted larger and far more complex shows, often in locations other than the Museum ${ }^{13}$.

One consistently important factor has been the varied contribution of specialists and scholars to the Institute's research activities, often resulting in significant publications. Another such collaborative effort was the cataloguing of the instruments and the preparation of a special description form for historical instruments. Initially designed by the Museum, the form was gradually improved until its adoption as a national template with the cooperation of the Ministry of Culture's Central Institute for Cataloguing and Documentation.

Thanks to its growing ties with Italian and foreign institutions, the Museum has taken part in European projects focusing attention on museum issues and scientific instruments. One notable example is EPACT: Scientific Instruments of Medieval and Renaissance Europe, ${ }^{14}$ a pilot project for the compilation of a database on measuring instruments from the Middle Ages to 1600, in which the British Museum of London, the Museum Boerhaave of Leiden, the Museum of the History of Science of Oxford, and the Institute and Museum of the History of Science of Florence took part. The results are still accessible online.Another example is WorldView Network - Culture 2000, a partnership involving five institutions: Landskrona Kulturförvaltning och Tycho Brahe Museet in Ven (Sweden), the Muzeum Nikolaja Kopernica in Frombork (Poland), the Národní Technické Muzeum in Prague (Czech Republic), the National Trust of Woolsthorpe Manor (United Kingdom), and the Florentine Museum . Each of these institutions represented an astronomer: Tycho Brahe, Copernicus, Kepler, Newton and Galileo respectively. ${ }^{15}$ These projects have made it possible to study certain measuring instruments in greater depth, broaden research on scientists of the past, and intensify cooperation between specialists in various fields. They have produced congresses and exhibitions, as well as fostering ties that have strengthened over the years even beyond the boundaries of the projects and independently of them.

The Institute's intense research activity also had an impact on the organization of the Museum. New studies led to new attributions for certain instruments, archival investigations added to the information on our collection, and the growing contacts with Italian and international institutions made the Museum an increasingly active node in a wide network of cooperative ventures on specific topics.

While research and scholarship forged ahead, however, the Museum was faced with ever more pressing practical issues. By the mid-1980s, the need for compliance with safety and fire-prevention standards obliged the Museum to refurbish the first floor, which was closed in 1986, while the second floor remained open to the public. The illustrated panels were a true novelty. Previously, the only information sources for visitors were self-guide cards. Now, panels placed in every room gave an introduction to the room theme and a detailed description of the types of instruments on view, with relevant illustrations. Information

13 Some of these events have been so successful that they have traveled to prestigious venues in Italy and abroad.

I 4 See http://www.mhs.ox.ac.uk/epact/.

15 The WorldView Network project culminated in the preparation of the show entitled "Machina Mundi: Images and Measures of the Cosmos from Copernicus to Newton," which traveled in the five partner countries. See http://brunelleschi.imss.fi.it/machinamundi/index.html. 
technology was not yet available, and these images consisted simply of photographs pasted directly on the panels.

The first floor thus refurbished was reopened in 1987 with the show entitled "The Age of Galileo." (MINIATI, 1987)

The next objective was the second floor. The most ambitious plan involved not just a basic modernization, but an entirely redesigned installation with display cases that would meet higher conservation standards and enhance the presentation of the objects. The second floor was completed in 199I.The new exhibition design resembled that of the first floor in graphic and educational terms, but differed in its physical layout and lighting systems. On the first floor, no two display cases were alike, as nearly all of them were inherited from the previous installation and simply refurbished-or, if new, they had been built to resemble the others as closely as possible. On the second floor, instead, all the cases were new and of uniform appearance. They were designed for the conservation of the objects. Some of the display units could actually serve as storage for items not on view. As on the first floor, each room of the second floor had been curated by a specialist who had selected the objects, prepared the panel and label texts, and written essays and descriptions for the new, complete catalogue of the Museum (MINIATI, I99I).

This arrangement remained unchanged until a few years ago. The panels with pasted photographs did not hold up well over the years, and the lack of computer resources became an ever more glaring deficiency. Research allowed new attributions of objects, while the development of multimedia systems offered previously unthinkable communication opportunities, which had to be factored into future plans for the Museum. In 2010 the museum changed completely: new exhibitions galleries, new name, new multimedia applications.

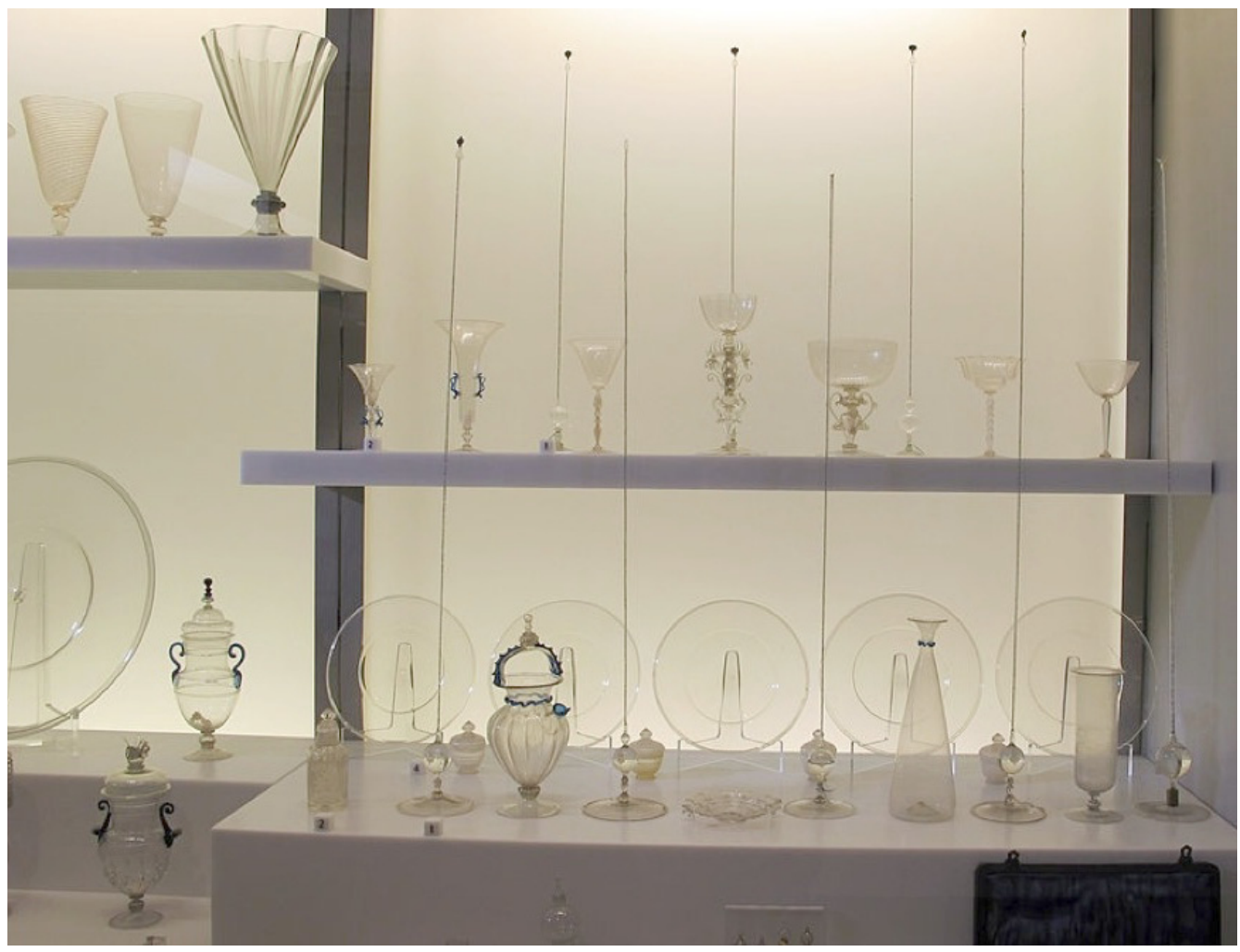


Let me conclude with some 'museological' consideration. I have always believed, and continue to believe, that the life of a museum revolves around three basic concepts: continuity, innovation, and "betrayal." For us, 'continuity' means appreciating the historical scientific heritage preserved by the Museum, and the unique value of the Medici and Lorraine instruments. 'Innovation' focuses on the ways to exhibit and explain that heritage, to make it "speak" and render it intelligible to a contemporary public. "Betrayal" should be understood as the ability to alter a "nineteenth-century" vision of the Museum, transform it, and introduce seemingly discordant elements that break with the past. In my view, the Institute and Museum of the History of Science-now the Museo Galileo-has embodied all three concepts, and that is the reason why its collections are living.

\section{References}

Arti del Medio Evo e del Rinascimento. Omaggio ai Carrand I889- I989, Firenze: SPES, 1989.

BARBAGLI Fausto. "Firenze e le Riunioni preunitarie degli scienziati italiani." In: MINIATI Mara (ed.), Firenze scienza. Le collezioni, i luoghi e i personaggi dell'Ottocento, Firenze: Edizioni Polistampa, 2009, pp.59-65.

"Il collezionismo naturalistico nel Museo di Fisica e Storia Naturale di Firenze di metà Ottocento." In: MINIATI Mara (ed.), Firenze scienza. Le collezioni, i luoghi e i personaggi dell'Ottocento. Firenze: Edizioni Polistampa, 2009, pp. I09-II7.

BAROCCHI, Paola, GAETA BERTELA'. I Carrand e il Collezionismo francese I820-। 888. Firenze: SPES, 1989.

BARONCELLI Giovanna, BUCCIANTINI Massimo, "Per una storia delle istituzioni storico-scientifiche in Italia. L'Istituto di storia della scienza di Firenze," Nuncius. Annali di Storia della Scienza, 1990, 5: 5-52.

BARTOLA Alberto, "Alle origini del Museo del Collegio romano. Documenti e testimonianze.” In: Nuncius. Annali di storia della scienza, XIX (2004), fasc. I, pp. 297-356.

BERETTA Marco."The Museum's installations beteween 1930 and 196I." In Displaying Scientific Instruments: from the Medici Wadrobe to the Museo Galileo. Milano, Goppion, Museo Galileo, 20 I2, pp. I09-II 5.

BERNACCHINI Sabina. “La fotografia e le scienze botaniche.” In: Rivista di storia della fotografia. n.46, 2007, pp. 18-42.

BERTANI, Licia, II Museo Horne: una casa fiorentina del Rinascimento. Firenze: Edizioni della Meridiana, 200I.

BONANNI Filippo, Musaeum Kircherianum sive Musaeum a p. Athanasio Kirchero incoeptum nuper restitutum, auctum, descriptum, et iconibus illustratum, Romae: Georg Plach, 1709.

BRENNI, Paolo. II Gabinetto di fisica dell'Istituto Tecnico Toscano. Guida alla visita, Firenze: Polistampa, 2009.

BRUSA, Giuseppe, GREGORIETTI Guido, TOMBA, Tullio. Orologi-Oreficerie. Milano: Electa, 1981.

BUCCIANTINI Massimo, “Before 1929”. In: F. Camerota (ed.), Displaying Scien- 
tific instruments: From the Medici Wardrobe to the Museo Galileo. Cittadella, Museo Galileo, Goppion, 2012 (“Annali del Laboratorio museotecnico”,V), pp. 77-93.

CAMEROTA Filippo (ed.), Displaying Scientific instruments: From the Medici Wardrobe to the Museo Galileo. Cittadella, Museo Galileo, Goppion, 2012 ("Annali del Laboratorio museotecnico", V).

. Museo Galileo. Capolavori della scienza, Firenze: Giun-

ti, 2010 (trad. Ingl. Museo Galileo. Masterpieces of science, Firenze: Giunti, 20 I0).

CAMEROTA Filippo, MINIATI Mara. I Medici e le scienze. Strumenti e macchine nelle collezioni granducali. Catalogue of the exhibition, Florence, Museo degli Argenti-Palazzo Pitti, I 5 May 2008-I I January 2009, Firenze: Giunti, 2008.

CERUTI Benedetto. CHIOCCO Andrea. Museum Francisci Calceolari, Verona: Angelo Tamo, 1622.

CONTARDI Simone. La Casa di Salomone a Firenze. L'Imperiale e Reale Museo di Fisic e Storia Naturale (1775-180I). Firenze: Leo S. Olschki, 2002.

CONTARDI Simone, MINIATI Mara. "Educating heart and mind:Vincenzo Antinori and scientific culture in Nineteenth century Florence". In:Archives Italiennes de Biologie. 149 (Suppl.): 57-62, 201 I.

CONTARDI Simone. “Vincenzio Antinori e il Gabinetto di Fisica del'Imperiale e Reale Museo di Fisica e Storia Naturale di Firenze.” In: MINIATI Mara (ed.), Firenze scienza. Le collezioni, i luoghi e i personaggi dell'Ottocento. Firenze: Edizioni Polistampa, 2009, pp.85-107.

DE SEPI, Giorgio. Romani Collegii Societatis Jesu Musaeum celeberrimum,Amstelodami: ex Officina Janssonio-Waesbergiana, 1678.

DEKKER Elly. Catalogue of Orbs, Spheres and Globes. Firenze: Giunti, 2004.

DI MARCO, Simona. Frederick Stibbert, 1838-1906: vita di un collezionista. Torino:Allemandi, 2008.

DRAGONI Giorgio. "Lord George Cowper's I8th Century Cabinet of Physics." In: Proceedings of the Eleventh Scientific Instrument Symposium. G. Dragoni, A. McConnell, G.L'E. Turner eds., Bologna: Grafis Edizioni, I994, pp. I9I-I99.

Enciclopedismo in Roma barocca: Athanasius Kircher e il Museo del Collegio romano tra Wunderkammer e museo scientifico, M. Casciato, M.G. lanniello, M. Vitale eds., Venezia: Marsilio, 1986.

Felice Fontana and his collections (M. Miniati ed.), in Nuncius, vol XXI, 2-2006, p.247-368

FUCHS, Dominique Charles, DI MARCO Simona. II Museo Stbbert: la casa museo. Firenze: Sillabe, 2003.

GALLUZZI Paolo (ed.). Novità celesti e crisi del sapere. Atti del Convegno Internazionale di studi galileiani. Supplement to Annali dell'Istituto e Museo di Storia della Scienza, 1983, n. 2.

GALLUZZI Paolo (ed.),Scienziati a Corte. L'arte della sperimentazione nell'Accdemia Galileiana del Cimento. Firenze: Sillabe, 200 I.

L'eredità scientifica di Leopoldo Nobili: dibattito teorico e ruolo degli strumenti nella fisica del primo Ottocento, Reggio Emilia: Comune di Reggio Emilia, 1984. 
GALLUZZI Paolo, Galileo Galilei: la nuova scienza e i suoi strumenti, in CAMEROTA Filippo (ed.), Museo Galileo. Capolavori della scienza, Firenze: Giunti, 2010 (trad. Ingl. Museo Galileo. Masterpieces of science, Firenze: Giunti, 20 I0), p. $153-165$

GIATTI, Anna, Lotti, Stefania (eds.). Le stanze della scienza. Le collezioni dell'Istituto Tecnico Toscano a Firenze. Firenze:Artigraf, 2006.

LEGATI Lorenzo. Museo Cospiano annesso a quello del famoso Ulisse Aldrovandi, Bologna: Giacomo Monti, 1677.

Leopoldo Nobili e la cultura scientifica del suo tempo. Convegno di studi per la celebrazione del secondo centenario della nascita - Reggio Emilia, 25-27 ottobre 1984,"Giornale di Fisica”, XXV (1984), 3-4, p. I63-385.

MAZZOLINI Renato. Omaggio a Felice Fontana (I730-|805), Rovereto: Osiride, 2005.

MESCHIARI Alberto. Microscopi Amici nella ricerca scientifica. Firenze, Fondazione Giorgio Ronchi, 2014.

MINIATI Mara (ed.). Firenze scienza. Le collezioni, i luoghi e i personaggi dell'Ottocento. Firenze: Edizioni Polistampa, 2009.

MINIATI Mara. Museo di storia della scienza. Catalogo, Firenze: Giunti, 1991. . “A 'museum to browse'." In: F. Camerota (ed.), Displaying Scientific instruments: From the Medici Wardrobe to the Museo Galileo. Cittadella, Museo Galileo, Goppion, 2012 (“Annali del Laboratorio museotecnico”, V), pp. II 7-I 27.

."From the Museum of Physics to the Museum of Ancient Instruments.” In: F. Camerota (ed.). Displaying Scientific instruments: From the Medici Wardrobe to the Museo Galileo. Cittadella, Museo Galileo, Goppion, 2012 (“Annali del Laboratorio museotecnico",V), pp.37-55.

L'età di Galileo. Il secolo d'oro della scienza in Toscana. Firenze: Istituto e Museo di Storia della Scienza, 1987.

"Orologi e strumenti scientifici." In: La storia del Bargello. B.

Paolozzi Strozzi ed., Firenze: Silvana Editoriale, 2004, pp. 263-275.

Strumenti scientifici della collezione Carrand. Firenze: Museo Nazionale del Bargello, 199I.

."Strumenti scientifici." In: Museo Bagatti Valsecchi. Tomo I, Milano: Electa, 2003, pp. 197-206.

"Toward the Museum of the year 2000.” In: F. Camerota (ed.), Displaying Scientific instruments: From the Medici Wardrobe to the Museo Galileo. Cittadella, Museo Galileo, Goppion, 2012 ("Annali del Laboratorio museotecnico",V), pp. I4I-I49.

Museo o Galeria adunata dal sapere e dallo studio del Sig. Canonico Manfredo Settala, Tortona: figli di Eliseo Viola, 1666.

Restituzioni 2004. Tesori d'arte restaurati (Vicenza 20 marzo-20 giugno 2004), Treviso: Banca Intesa, 2004, pp. 258-263.

SETTLE Thomas B.. "Gli strumenti astronomici di Santa Maria Novella.” In: CAMEROTA Filippo, MINIATI Mara. I Medici e le scienze. Strumenti e macchine 
nelle collezioni granducali. Catalogue of the exhibition, Florence, Museo degli Argenti-Palazzo Pitti, 15 May 2008-II January 2009, Firenze: Giunti, 2008, Pp. I87-19|.

STENDARDO Enrica. Ferrante Imperato. Collezionismo e studio della natura a Napoli tra Cinque e Seicento. Napoli:Accademia Pontaniana, 200 I (Quaderni dell'Accademia Pontaniana" 31 ).

TAROZZI Gino (ed.). La scienza degli strumenti. Giovanni Battista Amici ottico, astronomo e naturalista, «Giornale di Fisica», 2/3-I988.

TOTARO Giuseppina. “Da Antonio Magliabechi a Philip Von Stosch.” In: CANONE Eugenio (ed.), Bibliothecae selectae: da Cusano a Leopardi. Firenze: Olschki, 1993, pp. 377-44I.

ZAMBELLI Paola.Astrologia, magia e alchimia nel Rinascimento fiorentino e europeo, Firenze: Edizioni Medicee, 1980.

Artigo recebido em janeiro de 2016. Aprovado em abril de 2016 